This item was submitted to Loughborough's Research Repository by the author.

Items in Figshare are protected by copyright, with all rights reserved, unless otherwise indicated.

\title{
The legacy and the tyranny of time: exit and re-entry of sovereigns to international capital markets
}

PLEASE CITE THE PUBLISHED VERSION

https://doi.org/10.1111/jmcb.12474

\section{PUBLISHER}

(c) The Ohio State University. Published by Wiley

\section{VERSION}

AM (Accepted Manuscript)

\section{PUBLISHER STATEMENT}

This is the peer reviewed version of the following article: AGNELLO, L., CASTRO, V. and SOUSA, R.M., 2017. The legacy and the tyranny of time: exit and re-entry of sovereigns to international capital markets. Journal of Money, Credit and Banking, 50 (8), pp.1969-1994, which has been published in final form at https://doi.org/10.1111/jmcb.12474. This article may be used for non-commercial purposes in accordance with Wiley Terms and Conditions for Use of Self-Archived Versions.

\section{LICENCE}

CC BY-NC-ND 4.0

\section{REPOSITORY RECORD}

Agnello, Luca, Vitor Castro, and Ricardo M. Sousa. 2018. "The Legacy and the Tyranny of Time: Exit and Reentry of Sovereigns to International Capital Markets". Loughborough University.

https://hdl.handle.net/2134/26418. 


\title{
The Legacy and the Tyranny of Time:
}

\section{Exit and Re-Entry of Sovereigns to International Capital Markets*}

Luca Agnello ${ }^{\dagger}$
Vítor Castro ${ }^{\ddagger}$

\begin{abstract}
We use a novel continuous-time Weibull model (without and) with a change-point in the duration dependence parameter to investigate the duration of the exit and re-entry of sovereigns to international capital markets. Relying on annual data for a large panel of countries over the period 1970-2011, we find that, as the reputation of debtor countries as good (bad) borrowers solidifies over time, those episodes are more likely to end - i.e. the "legacy of time". Debtor countries can take advantage of the "benefit of doubt" of creditors during short exit spells. However, when exits are long and the reputation as a bad borrower emerges, no more "complacency" makes it more difficult for them to borrow again in international capital markets - i.e. the "tyranny of time". We also find that: (i) government stability and multilateral financial assistance play a crucial role; (ii) the dynamics of the duration of exit (re-entry) spells is robust to the presence of default episodes, the default length and the haircut size; and (iii) exit and re-entry have shortened over time.
\end{abstract}

Keywords: International capital markets, entry and exit, continuous-time Weibull model, duration dependence, change-point.

JEL codes: C41, G15.

\footnotetext{
* We are grateful to the Editor, Pok-Sang Lam, and an anonymous reviewer for their constructive comments and suggestions that considerably improved this paper. Castro and Sousa acknowledge that this work was carried out within the funding with COMPETE reference ${ }^{\circ}$ POCI-01-0145-FEDER-006683, with the FCT/MEC's (Fundação para a Ciência e Tecnologia, I.P.) financial support through national funding and by the ERDF through the Operational Programme on "Competitiveness and Internationalization - COMPETE 2020" under the PT2020 Partnership Agreement.

${ }^{\dagger}$ University of Palermo, Department of Economics, Business and Statistics (SEAS), Viale delle Scienze, 90128 Palermo, Italy. Email: luca.agnello01@unipa.it.

₹ Loughborough University, School of Business and Economics, Loughborough, Leicestershire LE11 3TU, United Kingdom; University of Minho, Economic Policies Research Unit (NIPE), Campus of Gualtar, 4710-057 - Braga, Portugal. Email: V.M.Q.Castro@lboro.ac.uk.

${ }^{\S}$ University of Minho, Department of Economics and Economic Policies Research Unit (NIPE), Campus of Gualtar, 4710-057 - Braga, Portugal; London School of Economics, LSE Alumni Association, Houghton Street, London WC2 2AE, United Kingdom. E-mails: rjsousa@eeg.uminho.pt, rjsousa@alumni.lse.ac.uk.
} 


\section{Introduction}

Borrowing in international capital markets is one of the most important sources of funding for open economies and sovereigns often use them to sell their bonds to foreign investors or obtain loans from foreign banking institutions (Esteves and Jalles, 2016). Moreover, although governments are generally immune from bankruptcy procedures and only a few of their assets can be seized in the case of a default, exiting from international capital markets carries important costs.

Yet, over the past century, a number of sovereigns have experienced episodes of loss of access to international capital markets. The empirical evidence tells us that some of these events lasted for long time spells and, in some cases, nations were forced to default (Beers and Chambers, 2006; Dhillon et al., 2006). However, it also suggests that, in the majority of cases, they were relatively successful in returning to a situation where they could borrow again in international capital markets.

Against this backdrop, several questions emerge: Are episodes of exit and reentry by sovereigns to international capital markets more likely to end as time goes by i.e., what is the "legacy of time"? Is the transition between episodes more difficult once they lasted for a certain amount of time i.e., what is the "tyranny of time"?

These issues touch upon different areas of research. One strand of the literature looks at capital flows and its determinants. In particular, our paper is related to: (i) the question of whether capital flows are pulled into a country by its success or pushed into a country by the lack of opportunities in other economies (Fernandez-Arias, 1996); (ii) the linkages between capital flows, external positions and local savings (Calvo, 1998; Reinhart and Talvi, 1998); and (iii) the institution-based determinants of capital flows, including low corruption and well-functioning bureaucracy (Wei, 2000; Portes and Rey, 2005; Gelos and Wei, 2005; Papaioannou, 2009).

We are also inspired by the research that assesses the motives behind the ability or the preference of sovereigns for meeting their debt obligations. In this case, authors have stressed the importance of the balance sheet effects of the ownership of sovereign debt by the domestic sector, the costs in terms of collateral and reputation, the direct sanctions or the threat of a embargo on future loans in the case of a default (Eaton and Gersovitz, 1981; Bulow and Rogoff, 1989; Fernandez and Rosenthal, 1990; Arteta and Hale, 2008; Guembel and Sussman 2009; Broner and Ventura 2010). ${ }^{1}$

\footnotetext{
${ }^{1}$ Sovereign debt repayments occur because governments worry that they may be forced to exit from international capital markets. This acts as a deterring mechanism (Kletzer and Wright 2000; Sandleris,
} 
While there may be important arguments for sovereigns not to default, sometimes, they do lose access to international capital markets. Our paper aims at capturing the dynamics of the length of market exit spells that is put forward by the theory and the empirical evidence. From a theoretical perspective, Diamond (1989) and Cole et al. (1995) argue that sovereigns cannot borrow again (after a default or a debt restructuring) until they have significantly rebuilt their reputation. Bi (2008) suggests that the delays in the debt renegotiation process increase the size of the "cake", thus, being mutually beneficial for lenders and borrowers. From an empirical point of view, Trebesch (2008) shows that the average duration from the start of debt distress until the final debt renegotiation deal is largely driven by fiscal measures and political instability, while in Arellano (2008) the exclusion from international capital markets is stochastically determined, thus, being independent from country characteristics and global financial conditions. Cruces and Trebesch (2013) claim that higher creditor losses are associated with longer periods of market exclusion.

Finally, despite exiting international capital markets, the experience shows that sovereigns re-enter after a certain amount of time. Our work investigates the determinants of the duration of market re-entry spells. In this context, the existing studies confirm the relevance of sound domestic policies and external positions, institutional quality and the country's reputation in explaining the access to international capital markets (Fostel and Kaminsky, 2007; Gelos et al. 2011; Zanforlin, 2007).

We make four important contributions to the existing literature. First, we take the issue of time very seriously. Thus, instead of looking at international capital flows per se (namely, their terms and volumes) or the timing of an exit from or a re-entry to international capital markets, we focus on the duration of these time spells. In an analogy with economic crises or unemployment, as relevant as predicting their exact time of occurrence or knowing what its rate might be at a given moment in time, it is their duration (thus, their severity) that concerns policymakers the most because of the associated welfare implications. $^{2}$

Second, we consider the duration of exit and re-entry of sovereigns to international capital markets through the lens of the "legacy of time". That is, we use a

2008; Andrade, 2009). Kohlscheen and O’Connell (2007) and Esteves and Jalles (2016) point out that, following a default, there is a fall or rationing in the access to long-term credit and foreign investment.

${ }^{2}$ As Kiefer (1988, p. 646) puts it: "... the unemployment rate, which involves both the incidence (or occurrence) of unemployment spells and their durations, is a less useful statistic than is the average duration of unemployment". 
novel methodology based on a continuous-time Weibull duration model to investigate whether the likelihood of the end of exit and re-entry spells increases or falls as these events become longer (older). Put it differently, we try to uncover the presence of duration dependence in those periods.

Third, we take one step forward and test the extent to which the likelihood of exit (re-entry) coming to an end changes after a certain duration. That is, instead of assuming that the dynamics of duration dependence is smooth over time, we evaluate the existence of a change-point in the duration dependence parameter. In this way, we assess if the likelihood of exit (re-entry) ending changes not only over time but also when it already lasted longer than a certain duration. We label this nonlinearity as the "tyranny of time". To the best of our knowledge, our study is also the first to provide an empirical investigation of this important dimension of international capital markets.

Fourth, we complement the analysis by addressing the key economic, financial and political drivers of the duration of periods of international capital markets' exit and re-entry. Additionally, we account for the role played by multilateral financial assistance and assess the importance of the occurrence of default episodes.

In our paper, we start by identifying episodes of exit (re-entry) of sovereigns from (to) international capital markets and measure their duration as the number of years over which net transfers of long-term bonds and commercial bank loans from private creditors to either the public and the publicly guaranteed sector or the private sector are negative (positive). Then, we use a continuous-time Weibull duration model and data for a large panel of developed and developing countries over the period 19702011 to assess the importance of the "legacy" and the "tyranny" of time, as well as other factors behind the pace and speed at which periods of international capital markets' exit and re-entry by sovereigns are likely to end.

Our empirical findings of a positive duration dependence in exit and re-entry spells are consistent with the idea of reputation as an important factor in sovereign lending (Eaton and Gersovitz, 1981). This "legacy of time" reflects the "marginal value of the reputation" of the debtor country and how strongly it is committed to keep it: conditional on having exited international capital markets, sustaining a good reputation contributes to the transition to another state of the world (i.e. to re-entry).

Next, we find evidence of the "tyranny of time". More specifically, when the exit (re-entry) has a duration that is shorter than 12 (9) years, each additional year of duration, on average, increases the likelihood of the end of the time spell by 6.24 (6.64) 
percentage points. In contrast, for markets' exit (re-entry) spells that are longer than 12 (9) years, each additional year of duration raises the likelihood of their end by just a tiny $0.49(0.45)$ percentage points. Therefore, the "break-point" in the duration dependence parameter defines "the length of the complacency" of the creditor country: for relatively short exit spells, the passage of time makes the agreement between creditors and debtors more likely to be settled, thus, the possibility of borrowing again from international capital markets. However, when the exit from international capital markets is relatively long, the passage of time leads to the emergence of a bad reputation, whereby the debtor country cannot be trusted by the creditor country as honoring (or as being able to honor) its promises. ${ }^{3}$ Consequently, no additional complacency makes it more and more difficult for the borrower to leave a "bad state" equilibrium - thus, the "tyranny of time".

We also show that government stability is key for sovereigns to be able to shorten episodes of exit from international capital markets. IMF-supported programs significantly affect exit and re-entry spells and, in general, both episodes have become shorter over time. Our main empirical findings are also robust when we: (i) account for the default length or the haircut size; (ii) focus on past defaulters; (iii) consider potential outliers; and (iv) use an alternative identification procedure.

The remainder of the paper is structured in the following way. In Section 2, we describe the econometric framework and the data used in the estimations. Section 3 provides a discussion of the empirical results and the sensitivity analysis. Finally, in Section 4, we conclude and highlight the main policy implications.

\section{Econometric framework and data}

\subsection{The baseline Weibull model}

To capture the "legacy of time" on the length of exit and re-entry of sovereigns to international capital markets, we consider the following continuous-time Weibull duration model

$$
h(t, \mathbf{x}) ? h(t) \cdot \mathrm{I}(\mathbf{x}) ? \operatorname{lpt}^{p / 1} \cdot \exp \left(\mathbf{x}^{\bullet}\right),
$$

where $h(t, \mathbf{x})$ is the hazard function, $h(t) ? u p t^{p / 1}$ is the baseline hazard function, $p$ is the duration dependence parameter, I $(\mathbf{x}) ? \exp \left(\mathbf{x}^{\bullet}\right)$ is a function of the data where $\mathbf{x}$ is a

\footnotetext{
${ }^{3}$ Benjamin and Wright (2009) also note that although a debt restructuring agreement generates surpluses not only in the future but also at the time of the settlement, the creditor and the debtor countries find it optimal to delay it to the future when the default risk is lower, the promise of the debtor to share the surplus with the creditor is more credible and the access to capital markets is more valuable.
} 
vector of control variables and - is the $(\mathrm{k} \times 1)$ vector of associated parameters, $t$ corresponds to time, and ...is a positive constant (i.e. ...0). In this framework, $p>1$ implies positive duration dependence, $p<1$ implies negative duration dependence, and $p=1$ implies no duration dependence.

The baseline hazard function traces the rate at which an event spell will end at time $t$, given that it lasted until then. In our study, it denotes the probability of the end of exit (re-entry) by sovereigns from (to) international capital markets at time $t$ conditional on the age i.e. the duration of the exit (or re-entry). More importantly, it characterizes the path of duration dependence, i.e. what we label as "the legacy of time". ${ }^{4}$

From the hazard function, we derive the integrated hazard function, $H(t) ? \int h(u) d u$, and compute the survival function, $S(t)$ ? $\exp [/ H(t)]$. Given the functional form described by Equation (1), $S(t, \mathbf{x}) ? \exp \left[/ \iota t^{p} \exp \left(\mathbf{x}^{\bullet}\right)\right]$. Then, the model is estimated by Maximum Likelihood and the log-likelihood function, for a sample of $i=1, \ldots, n$ entry (re-entry) time spells, is given by:

$$
\begin{aligned}
\ln L(\cdot) & ? \sum_{i ? 1}^{n}\left[c_{i} \ln h\left(t_{i}, \mathbf{x}_{i}\right)-\ln S\left(t_{i}, \mathbf{x}_{i}\right)\right] ? \\
& ? \sum_{i ? 1}^{n}\left[c_{i}\left(\ln \imath-\ln p-(p / 1) \ln t_{i}-\mathbf{x}_{i} \bullet\right) / l t_{i}^{p} \exp \left(\mathbf{x}_{i}^{\bullet}\right)\right],
\end{aligned}
$$

where $c_{i}$ indicates when observations are censored. If the sample period under analysis ends before the transition between the two events (i.e. exit and re-entry) has been observed, then observations will be censored (i.e. $c_{i}=0$ ); and when the transition between the two events (i.e. exit and re-entry) are observed in the sample period, the observations are not censored (in which case, $c_{i}=1$ ).

\subsection{The Weibull model with a change-point}

We now consider the possibility that the likelihood of the end of exit and reentry to international capital markets, as these time spells get older, changes after a certain duration. More specifically, we assess whether the parameters of the baseline hazard function (i.e. $p$ and ..). vary over time for different time intervals, but remain

\footnotetext{
${ }^{4}$ Duration analysis has been increasingly used in economics (Kiefer, 1983) with the seminal applications concerning study of the length of unemployment (Kiefer, 1984, 1988) and business cycles phases (Sichel, 1991). More recently, other authors investigate the presence of duration dependence in business cycle expansions and recessions (Castro, 2010), stock markets' bull and bear cycles (Lunde and Timmermann, 2004), house price upturns and downturns (Bracke, 2013), fiscal consolidation programs (Agnello et al., 2013) and booms, busts and normal times in the housing markets (Agnello et al., 2016).
} 
constant within each interval. Thus, we estimate a Weibull model with a break-point in the duration dependence parameter $\left(t_{c}\right){ }^{5}$ Apart from granting more flexibility in terms of modelling, this framework allows us to evaluate the extent to which the hazard function exhibits some nonlinearity over time, thus, making it possible to investigate the "tyranny of time".

We start by assuming that ...!? and, thus, re-write Equation (1) as

$$
h(t, \mathbf{x}) ? h(t) \cdot \mathrm{I}(\mathbf{x}) ? v p(v t)^{p / 1} \cdot \exp \left(\mathbf{x}^{\bullet}\right),
$$

which implies that the survival function becomes $S(t, \mathbf{x}) ? \exp \left[/(v t)^{p} \exp \left(\mathbf{x}^{\bullet}\right)\right]$.

If we denote $g(t)=\ln H(t)$ and assume that it is continuous at the change-point, $t_{c}$ (i.e. $\ln \left(v_{1} t_{c}\right)^{p_{1}} ? \ln \left(v_{2} t_{c}\right)^{p_{2}}$ is satisfied) and for any two intervals, $t_{0}<t \hat{O}_{c}$ and $t_{c}<t \hat{O}_{T}$, then the log-likelihood function can be expressed as:

$$
\ln L(\cdot) ? \sum_{i ? 1}^{n}\left\{c_{i}\left[\ln g^{\prime}\left(t_{i}\right)-g\left(t_{i}\right)-\mathbf{x}_{i}^{\bullet}\right] / \exp \left[g\left(t_{i}\right)-\mathbf{x}_{i}^{\bullet}\right]\right\}
$$

where $g^{\prime}(t) ? d_{i} \frac{p_{1}}{t_{i}}-\left(1 / d_{i}\right) \frac{p_{1}}{t_{i}} \frac{\ln \left(v_{1} t_{c}\right)}{\ln \left(v_{2} t_{c}\right)} ? d_{i} \frac{p_{1}}{t_{i}}-\left(1 / d_{i}\right) \frac{p_{2}}{t_{i}}$, with $d_{i}=1$ (i.e. $\left.t_{0}<t \hat{O}_{c}\right)$ and $d_{i}=0$ (i.e. $t_{c}<t \hat{O}_{T}$ ), and $i=1, \ldots, n$ entry (re-entry) time spells. Finally, the model is estimated by Maximum Likelihood, with the statistical significance of the change in the duration dependence parameter between the two sub-periods (i.e. of the statistical significance of the change-point, $t_{c}$ ) being evaluated by the difference between $p_{1}$ and $p_{2}$.

\subsection{Data}

We gather data from the World Bank's Global Development Finance - World Development Indicators (GDF-WDI) on both private and public borrowing for 121 developed and developing countries over the period 1970-2011. ${ }^{6}$

We consider net bank or bond transfers from private creditors to either the private sector or the public and the publicly guaranteed sector. ${ }^{7}$ Private borrowing includes: (1) non-guaranteed long-term debt from bonds that are privately placed (i.e. the variable 'DT.NTR.PNGB.CD: PNG, bonds'); and (2) non-guaranteed long-term commercial bank loans from private banks and other private financial institutions (i.e.

\footnotetext{
${ }^{5}$ For an application of the Weibull model with change-points to investigate the duration of business cycle expansions and contractions, see Castro (2013). Agnello et al. (2015a) use the same framework to assess the presence of a break-point in the duration of housing booms, busts and normal times, while Agnello et al. (2015b) rely on it to evaluate the evidence of fiscal fatigue in fiscal consolidations.

${ }^{6}$ The list of countries included in the analysis is reported in the Appendix.

${ }^{7}$ Net transfers of debt among private sector entities (even if they may be coordinated by the public sector) are not taken into account.
} 
the variable 'DT.NTR.PNGC.CD: PNG, commercial banks and other creditors'). Public borrowing corresponds to the sum of: (3) public and publicly guaranteed debt from bonds that are either publicly issued or privately placed (i.e. the variable 'DT.NTR.PBND.CD: PPG, bonds'); and (4) public and publicly guaranteed commercial bank loans from private banks and other private financial institutions (i.e. the variable 'DT.NTR.PCBK.CD: PPG, commercial banks'). The sum of these four components corresponds to total borrowing. Thus, net transfers amount to the difference between net flows and interest payments during the year.

We assume that if net negative transfers made by the borrower to the creditor during the year are negative, there is the exit of a sovereign from international capital markets in that year; by contrast, if net transfers of bank loans and bonds are positive, the sovereign re-enters international capital markets. Therefore, we create a dummy variable that takes the value of one during an exit from international capital markets, and zero otherwise; and another dummy variable that takes the value of one when reentry occurs, and zero otherwise.

Finally, we measure the respective duration of each event. Thus, the dependent variables of our duration models are defined as either the number of years that a sovereign has exited international capital markets (for which net bank and bond transfers are negative, i.e. an exit spell), or the number of years that a sovereign has reentered them (for which net bank and bond transfers are positive, i.e. a re-entry spell).

Our measures do not aim at differentiating between "supply" and "demand" factors behind the willingness of a government to borrow internationally. ${ }^{8}$ For instance, loans from international organisations may be available at more appealing terms, whereby exit and re-entry would mainly reflect a decision of credit suppliers. ${ }^{9}$ Alternatively, the relevance of international capital markets as a source of funding may be secondary in the case of a large and captive pool of domestic savings.

\footnotetext{
${ }^{8}$ Such distinction faces three major challenges: (i) data for yields on sovereign debt or interest payments on debt expressed as a share of general government revenue are not available for a large number of (emerging market) economies (Debrun and Kinda, 2013); (ii) we would need to make an "ad-hoc" decision vis-à-vis the threshold for the sovereign debt yield (or other "price" indicator) above or below which one can identify episodes of exit or re-entry; (iii) the empirical relationship between sovereign spreads and episodes of exit or re-entry is not as conclusive as that based on capital flows (Kaminsky and Schmukler 2002; Clemens and Williamson 2004; Reinhart and Rogoff, 2004; Das et al. 2010). For a discussion of the difficulties in the identification of the supply and demand factors behind the drivers of countries' borrowing ability, see also Gelos et al. (2011).

${ }^{9}$ For this reason, net transfers of debt affecting official creditors, such as loans from the International Bank for Reconstruction and Development (IBRD) and credits from the International Development Association (IDA) that are provided under the chairmanship of the Paris Club are excluded.
} 
Yet, they allow us to understand if a country re-enters international capital markets even if it does not borrow, as a relatively good financial health is a precondition for borrowing from abroad. Moreover, they distinguish re-entry from situations in which sovereigns simply roll over their existing debt and issue new debt instead of writing it down (Eaton, 1992). Additionally, they are typically related with events of distressed sovereign debt restructurings with foreign commercial creditors (Trebesch, 2008; Enderlein et al., 2012; Cruces and Trebesch, 2013). Finally, our approach, which relies on the "quantity" of capital flows, does not weaken the identification of exit or re-entry spells, ${ }^{10}$ as we account for various factors that may affect these episodes more in some countries than others.

Among the determinants of the duration of periods of exit and re-entry by sovereigns to international capital markets, we consider:

- Regional variables (i.e. dummy variables for Asia-Pacific, Latin America, Middle East, Africa, Europe, and North America), which allow us to analyze potential unobserved heterogeneity across regions.

- Decade variables (i.e. Dec70, Dec80, Dec90 and Dec00 dummy variables), to assess if the duration of exit or re-entry has changed over time. As we rely on a continuous-time duration model, these time dummies represent the decade that contains the end of a spell.

- Order of event over time and for each country. This variable is equal to one for the first event, two for the second event and so on. If the associated coefficient is statistically significant and larger (smaller) than zero, exit and re-entry spells gradually become shorter (longer) over time.

- Duration of previous event, which tests whether the duration of the previous spell affects the length of the current spell.

- Default episodes, which is a dummy variable that takes the value of one during events of default, as proxied by the selective default rating compiled by the Cavanaugh et al. (2013), and zero otherwise. Thus, this variable

\footnotetext{
${ }^{10}$ For instance, only $4.2 \%$ of the sample shows net positive transfers during periods of default, of which 8.1\% represent net positive bond transfers and 3.7\% corresponds to net positive bank loan transfers. Thus, net bank or bond transfers from private creditors that are negative (positive) are a good measure of exit (re-entry) by sovereigns from (to) international capital markets.
} 
allows us to investigate if the duration of exit and re-entry spells is significantly different for defaulting and non-defaulting countries. ${ }^{11}$

- IMF-supported program, which is a dummy variable that indicates if a country is under an agreement with the IMF or not. This variable accounts for the potentially weak liquidity position of the country and the importance that multilateral financial assistance can play in easing it. Data are sourced from the Monitoring of Fund Arrangements (MONA) database of the IMF, and cover Extended Fund Facilities, Poverty Reduction and Growth Facility, and Stand-By Arrangements).

- Country size, which is a dummy variable that takes the value of one if the average GDP (in US dollars) of a given country exceeds the sample average GDP, and zero otherwise. Data are obtained from the World Bank's WDI.

- Risk rating along three dimensions: 1) economic; 2) financial; and 3) political. These are dummy variables that take the value of one if the index associated with a specific dimension of a country's risk rating exceeds the sample average, and zero otherwise. They summarize a panoply of factors that affect the duration of exit and re-entry spells. ${ }^{12}$ Data are collected from the International Country Risk Guide (ICRG).

The descriptive statistics of all the variables used in the empirical analysis are summarized in Table 1. We identify 561 spells of exit from international capital markets, which vary in terms of length from one year to 30 years; and 614 spells of reentry, with a duration that ranges between one and 42 years.

\section{[ INSERT TABLE 1 HERE. ]}

In Figure 1, we plot the survival function for exit (left panel) and re-entry (right panel) spells. It can be seen that the probability of exit (re-entry) from (to) international capital markets surviving after a certain duration substantially decreases over time. In the next Section, we investigate if this decline is consistent with the existence of

\footnotetext{
${ }^{11}$ Kaminsky et al. (1998), Mauro et al. (2006) and Gelos et al. (2011) show that the default history is a prominent determinant of sovereign spreads. Sturzenegger and Zettelmeyer (2007) highlight that credit rationing or market exclusion are an extreme form of punishment associated to default episodes. Catão and Mano (2017) also find that past defaulters are charged a large and persistent default premium.

${ }^{12}$ These include: economic risk rating (inflation, budget balance and current account as percentages of GDP, GDP per head and real GDP growth), financial risk rating (current account and foreign debt service as percentages of exports of goods and services, exchange rate stability, foreign debt as a percentage of GDP and net international liquidity as months of import cover) and political risk rating (investment profile, government stability and socioeconomic conditions).
} 
duration dependence and if the shape of the survival functions supports the presence of a change-point in the duration dependence parameter.

\section{[ INSERT FIGURE 1 HERE. ]}

\section{Empirical Results}

\subsection{The "legacy of time"}

We start by presenting and discussing the results of the estimation of the baseline continuous-time Weibull model for the duration of exit spells. In Table 2, we consider a basic model specification (column 1), which is then extended by adding the set of time-invariant control variables (columns 2-5). For each regression - apart from the estimated coefficients and the corresponding robust standard errors -, we report the number of spells, the log-likelihood function ( $\log L)$ and the Schwarz Bayesian Information Criterion (SBIC).

In general, the empirical evidence supports the presence of decreasing positive duration dependence as $p$ - the parameter that measures the magnitude of duration dependence - is not only significantly greater than 1 , but also significantly lower than 2 . Consequently, the probability of an exit spell ending increases over time at a falling pace. ${ }^{13}$ Positive duration dependence can, thus, be interpreted as "the marginal value of reputation": as time goes by, sovereigns solidify their reputation as good debtors and this contributes to the transition to re-entry spells - therefore, the "legacy of time".

To account for heterogeneity in the likelihood of the end of exit spells due to unmeasured covariates or measurement error, we control for regional and time effects (columns 2-5). All coefficients associated with the regional dummy variables are positive and significant. While their magnitude is similar, they suggest that being part of the European block is associated with shorter periods of exit from international capital markets. Exit spells also appear to be shorter in the 70s and 80s, which, possibly, reflects the shorter length of debt renegotiations or the higher frequency of occurrence of exits in those decades.

In addition, we find that: (i) the duration of exits of sovereigns from international capital markets has decreased over time (i.e. the coefficient associated with the order of the event is positive and significant); and (ii) the longer the previous spell is, the smaller the likelihood of the end of an exit spell.

\footnotetext{
${ }^{13}$ For details on the second-order derivative of the hazard function, see Castro (2010, 2013).
} 
Regarding other time-invariant controls, the results clearly corroborate the importance of government stability in shaping the duration of exit spells: in countries with a high political risk rating score - i.e. a low political risk -, the probability of the end of an exit spell is, approximately, 12.4 percentage points larger than in countries with a low score. ${ }^{14}$ They also indicate that when IMF-supported programs are in place, exit spells are longer, which is in line with these stabilization programs being implemented when sovereigns face very weak international positions. Other control variables (such as, the country size and economic and financial risk ratings) do not significantly affect the duration of the exit from international capital markets.

[ INSERT TABLE 2 HERE. ]

Table 3 summarizes the findings for the re-entry by sovereigns to international capital markets. As in the case of the exit spells, we show that, with the exception of the basic specification, there is positive duration dependence. In this case, the "legacy of time" implies that "the marginal value of the reputation" of a sovereign keeps eroding as time passes by, thus, making the end of re-entry spells more likely to occur.

Periods of re-entry have also become shorter over time. And having exited international capital markets for a long time can undermine the duration of re-entry. We also confirm the presence of unobserved heterogeneity. Therefore, we take it into account by adding geographical and decade dummy variables to the model. These reveal that re-entry spells are typically shorter in Africa and Latin America.

Concerning the role of economic, financial and political controls, we find a statistically significant effect of the presence of IMF-supported programs: in countries that experienced an agreement with the IMF, the likelihood of the end of a re-entry spell is, approximately, 14.7 percentage points lower than in those that never received IMF aid. Thus, the provision of multilateral financial assistance strengthens the supported countries and contributes to a faster re-entry to international capital markets.

[ INSERT TABLE 3 HERE. ]

\subsection{The "tyranny of time"}

In this Section, we allow for the possibility that, after a certain duration, the survival functions associated with exit and re-entry spells decline at a slower or faster pace. Indeed, a signal of the existence of a break-point in duration dependence for exit

\footnotetext{
${ }^{14}$ This is computed as $h(\hat{\imath}, \hat{p}, \hat{\delta}, \bar{t}, \overline{\mathbf{x}}$, Political risk rating ? 1)/ $h(\hat{\imath}, \hat{p}, \hat{\delta}, \bar{t}, \overline{\mathbf{x}}$, Political risk rating ? 0), where all regressors are evaluated at their means.
} 
and re-entry spells is provided by the slope of these functions: in the case of the exit from international capital markets, the average slope is equal to -0.0624 for spells that are shorter than 12 years and -0.0049 for those that last longer than 12 years; and for reentry, the average slope is equal to -0.0664 for spells that are shorter than 9 years and -0.0045 for those that last longer than 9 years.

After recursively testing for the statistical significance of alternative change points (see Figure 2), we confirm the following identification: 12 years for periods of exit from international capital markets; and 9 years for periods of re-entry. ${ }^{15}$ This means that the likelihood of the end of an exit spell that is shorter than 12 years is significantly different from that of an exit spell that is longer than 12 years; and, similarly, for reentry spells that are shorter or longer than 9 years.

Consequently, we need to estimate a Weibull model with a change-point in the duration dependence parameter. Put it differently, our model should include two duration dependence parameters: one for the shorter spells $\left(p_{1}\right)$ and another one for the longer spells $\left(p_{2}\right)$. Additionally, it should be noted that the decade dummies and the change-point model are related, as they both concern changing probabilities. While this may present a challenge in model identification, it is important to highlight that they are conceptually distinct. In fact, the former addresses variations of probabilities over time, and the latter addresses variations in probabilities due to the duration of a spell.

\section{[INSERT FIGURE 2 HERE]}

The results for both periods of exit and re-entry are reported in Table 4. We first estimate a basic model specification without covariates (columns 1 and 6) and, then, we include time-invariant control variables (columns 2-5 and 7-10). As can be seen from the estimates of $p_{1}$ and $p_{2}$, the duration dependence parameter is always significantly lower when the episodes of exit and re-entry to international capital markets last for more than 12 and 9 years, respectively. This can be seen in the difference $\left(p_{2}-p_{1}\right)$, which is negative and statistical significant. Thus, duration dependence is not the same across spells of different length.

Moreover, $p_{1}$ is statistically significant and larger than 1 regardless of the model specification, which implies that there is positive duration dependence for the shorter spells. In contrast, $p_{2}$ is smaller than 1 and either not significant or weakly significant,

\footnotetext{
15 The empirical evidence shows that these change-points also represent those that maximize the loglikelihood function. These results are available upon request.
} 
thereby, suggesting that there is either no duration dependence or negative duration dependence for the longer spells.

Consequently, in our study, the "change-point" in the duration dependence parameter measures the "tyranny of time". For short periods of exit from international capital markets, debtor countries take advantage of the "benefit of doubt" from creditor countries, which means that the probability of being able to borrow again from international capital markets increases as time goes by. However, the passage of time also implies that the reputation of debtor countries remains under check. So, when exit spells have been long enough and did not end, debtors no longer benefit from the "complacency" of creditors. This is what we call the "tyranny of time", whereby, it becomes more difficult for a country to borrow again in international capital markets.

From a quantitative point of view, our results imply that for exit spells shorter than 12 years, each additional year of duration, on average, increases the likelihood of their end by 6.24 percentage points; and, for longer exit spells, each additional year of duration raises the likelihood of their end by just 0.49 percentage points. Similarly, while for re-entry spells that are shorter than 9 years, each additional year of duration increases the likelihood of their end by 6.64 percentage points, in the case of longer episodes that probability raises by a tiny 0.45 percentage points.

Turning to the influence of time-invariant regressors, the results are broadly consistent with our previous findings for the Weibull model without change-points. First, heterogeneity across regions and decades is important. Second, more government stability (as proxied by a high political risk rating score) significantly shortens periods of exit of sovereigns from international capital markets. Third, the role of IMFsupported programs remains ambiguous. On the one hand, multilateral financial assistance is generally required when the international position of the debtor country is very weak, which implies a longer period without being able to borrow in international capital markets. On the other hand, it is typically conditional on the implementation of important structural reforms which boost potential output and, thus, speed up the return to a situation where sovereigns can borrow internationally. Finally, there is some evidence showing that past defaulters have longer exit and shorter re-access spells than countries without a history of default.

[ INSERT TABLE 4 HERE. ] 


\subsection{Sensitivity analysis}

In order to assess the sensitivity of our findings, we conduct a series of econometric exercises. For brevity, they are only reported for the Weibull model with change-points. ${ }^{16}$

In Table 5, we replace the dummy variable for default episodes with: (i) a dummy variable that takes the value of one if the default length is high (i.e. above the sample average), and zero otherwise (columns 1 and 5); or (ii) a dummy that takes the value of one if the size of the haircut is high (i.e. above the sample average), and zero otherwise (columns 2 and 6). These experiments are close in spirit with the work of Benjamin and Wright (2009), who show that larger debt haircuts are associated with longer periods of default. Additionally, we restrict our sample to past defaulters (columns 3 and 7). One obvious caveat of this exercise is that the number of exit and reentry spells substantially falls and, thereby, impacts on the precision of the estimates. Finally, we exclude OECD countries from the analysis (columns 4 and 8 ). ${ }^{17}$

The results are very close to those reported in Table 4. In fact, they unequivocally confirm the existence of positive duration dependence (as reflected by the value of $p_{1}$, which is significantly higher than 1 ) and the presence of a change-point in the duration dependence parameter with change points (in light of the statistical significance of the term $\left(p_{2}-p_{1}\right)$.

The evidence for the other control relative is also broadly consistent with our previous findings. Thus, even though the size of the coefficients slightly differs, we conclude that multilateral financial assistance from the IMF is pivotal for the duration of periods of exit from and re-entry to international capital markets. In addition, government stability is crucial to shorten the length of exit spells. Interesting, the results are not affected by the default length and the size of the debt haircut, which are not statistically significant.

\section{[ INSERT TABLE 5 HERE. ]}

In Table 6, we consider two additional experiments. First, we account for the presence of potential outliers and drop from the sample the countries with the longest exit and re-entry spells. As these countries may be classified as being in a long running exit or re-entry spell, their inclusion could ultimately imply that other countries have a

\footnotetext{
16 However, the empirical findings for the baseline Weibull model are both qualitatively and quantitatively similar and are available upon request.

${ }^{17}$ Because of the small number of observations, the same analysis cannot be performed for the sample of OECD countries.
} 
nil chance of ending a specific episode. Thus, we drop one (columns 1 and 3) or three outliers (columns 2 and 4) for the exit and re-entry spells, respectively. And, again, the empirical findings do not significantly vis-à-vis those reported in Table $4{ }^{18}$

Second, we consider an alternative identification of exit and re-entry episodes by including portfolio equity flows in our definitions. Specifically, periods of exit (reentry) of sovereigns from (to) international capital markets are defined as years over which the sum of net transfers of long-term bonds and commercial bank loans from private creditors to either the public and the publicly guaranteed sector or the private sector and portfolio equity flows is negative (positive). ${ }^{19}$

These definitions are based on the idea that such financing instruments may be substitutes or complements rather than mutually exclusive. In this context, we develop measures that include net flows of debt and equity. Data for portfolio equity net inflows ("BX.PEF.TOTL.CD.WD") are collected from the Global Development Finance World Development Indicators (GDF-WDI) database of the World Bank.

A summary of the empirical findings is reported in columns 5-6. They are in line with those where we rely on the original identification procedure. Thus, our conclusions regarding the "legacy" and the "tyranny" of time and the role played by government stability and IMF-supported programs remain unchanged.

[ INSERT TABLE 6 HERE. ]

\section{Conclusion}

We use a novel econometric framework to study the duration of episodes of exit (re-entry) of sovereigns from (to) international capital markets. Relying on a continuous-time Weibull model with and without a change-point in the duration dependence parameter and data for a large panel of countries over the period 19702011, our study provides four main findings.

First, as time goes by and the reputation of debtor sovereigns as good (bad) borrowers solidifies, periods of exit (re-entry) from (to) international capital markets are more likely to end - this is the "legacy of time".

\footnotetext{
${ }^{18}$ For the sake of space, the results for the Weibull model without break-points are not reported, but they are available upon request.

${ }^{19}$ Yet, it should be noted that, in contrast to the private sector which may raise capital through the sale of both debt and equity, public authorities generally raise capital via the issuance of debt in the form of bonds. Moreover, our original categorization of the exchange of domestic and external debt is in line with the work of Sturzenegger and Zettelmeyer (2007).
} 
Second, having exited international capital markets for short periods, debtor countries can take advantage of the "benefit of doubt" from creditor countries. However, when exit spells are long enough and the reputation as a bad borrower resumes, they no longer benefit from the "complacency" of lenders - this is the "tyranny of time".

Third, government stability and multilateral financial assistance have a significant influence on the length of exit and re-entry spells. Moreover, these have become shorter over time.

Fourth, the dynamics of the duration of periods of exit (re-entry) from (to) international capital markets is robust to the presence of default episodes, the default length and the haircut size.

From a policy perspective, our investigation is crucial for the design and the implementation of effective policies that are welfare-maximizing. For instance, by demonstrating a willingness to meet debt obligations and to re-build the reputation as a good borrower, governments can significantly shorten exit spells and, thus, minimize the associated exit costs. Similarly, by promoting a stable political environment, sovereigns can speed up the transition to a state of the world where they can borrow again from international capital markets.

Finally, any assessment about the potential costs of defaults or debt restructuring programs requires accurate information about the duration of exit (re-entry) spells, as the distribution of these episodes will reflect sovereigns' outside options. Therefore, our study can contribute to a better knowledge of market-based borrowing and the factors behind a continued access to international capital markets for long periods of time. 


\section{References}

Agnello, L., Castro, V., and R. M. Sousa, 2013. What determines the duration of a fiscal consolidation program? Journal of International Money and Finance, 37, 113-134.

Agnello, L., Castro, V., and R.M. Sousa, 2015a. Booms, busts and normal times in the housing market. Journal of Business \& Economic Statistics, 33(1), 25-45.

Agnello, L., Castro, V., and R.M. Sousa, 2015b. Is fiscal fatigue a threat to consolidation programmes? Environment \& Planning C: Government and Policy, 33, 765-779.

Agnello, L., Castro, V.; Sousa, R.M., 2016. Economic activity, credit market conditions and the housing market. Macroeconomic Dynamics, doi: doi:10.1017/S1365100516000869.

Andrade, S., 2009. A model of asset pricing under country risk. Journal of International Money and Finance, 28(4), 671-695.

Arellano, C. 2008. Default risk and income fluctuations in emerging economies. American Economic Review, 98(3), 690-712.

Arteta, C., and G. Hale, 2008. Sovereign debt crises and credit to the private sector. Journal of International Economics, 74, 53-69.

Beers, D., and J. Chambers, 2006. Default study: Sovereign defaults at 26-year low, to show little change in 2007. Standard \& Poor's Credit Week, 18 September.

Benjamin, D., and M.L.J. Wright, 2009. Recovery before redemption: A theory of delays in sovereign debt renegotiations. State University of New York, Buffalo, manuscript.

Bi, R., 2008. "Beneficial" delays in debt restructuring negotiations. International Monetary Fund, IMF Working Paper No. 38.

Bracke, P., 2013. How long do housing cycles last? A duration analysis from 19 OECD countries. Journal of Housing Economics, 22(3), 213-230.

Broner, F., and J. Ventura, 2010. Rethinking the effects of financial liberalization. National Bureau of Economic Research, NBER Working Paper No. 16640.

Bulow, J., and K. Rogoff, 1989. Sovereign debt: Is it to forgive to forget? American Economic Review, 79(1), 43-50.

Calvo, G., 1998. Capital flows and capital-market crises: The simple economics of sudden stops. Journal of Applied Economics, 1(1), 35-54. 
Castro, V., 2010. The duration of economic expansions and recessions: More than duration dependence. Journal of Macroeconomics, 32, 347-365.

Castro, V., 2013. The duration of business cycle expansions and contractions: are there change-points in duration dependence? Empirical Economics, 44, 511-544.

Catão, L., and R. Mano, 2017. Default premium. Journal of International Economics, 107, 91-110.

Catão, L., and M.E. Torrones, 2005. Fiscal deficits and inflation. Journal of Monetary Economics, 52, 529-554.

Cavanaugh, M., Phua, Y.F., and B.J. Young, 2013. Sovereign rating and country T\&C assessment histories. Standard \& Poor's Ratings Direct, January, 1-52.

Clemens, M., and J. Williamson, 2004. Wealth bias in the first global capital market boom, 1870-1913. Economic Journal, 114, 303-337.

Cole, H.L., Dow, J., and W.B. English, 1995. Default, settlement, and signalling: Lending resumption in a reputational model of sovereign debt. International Economic Review, 36(2), 365-385.

Cruces, J.J., and C. Trebesch, 2013. Sovereign defaults: The price of haircuts. American Economic Journal: Macroeconomics, 5(3), 85-117.

Das, U., Papaioannou, M., and C. Trebesch, 2010. Sovereign default risk and private sector access to capital in emerging markets. International Monetary Fund, IMF Working Paper No. 10.

Debrun, X., and T. Kinda, 2013. That squeezing feeling: The interest burden and public debt stabilization. International Monetary Fund, IMF Working Paper No. 125.

Dhillon, A., García-Fronti, J., Ghosal, S., and M. Miller, 2006. Debt restructuring and economic recovery: Analyzing the Argentine swap. World Economy, 29(4), 377-398.

Diamond, D.W., 1989. Reputation acquisition in debt markets. Journal of Political Economy, 97(4), 828-862.

Eaton, J., 1992. Sovereign debt: a primer. World Bank, Policy Research Working Paper No. 855.

Eaton, J., and M. Gersovitz, 1981. Debt with potential repudiation: Theoretical and empirical analysis. Review of Economic Studies, 48(2), 289-309.

Enderlein, H., Trebesch, C., and L. von Daniels, 2012. Sovereign debt disputes: A database on government coerciveness during debt crises. Journal of International Money and Finance, 31(2), 250-266. 
Esteves, R.P., and J.T. Jalles, 2016. Like father like sons? The cost of sovereign defaults in reduced credit to the private sector. Journal of Money, Credit and Banking, 48(7), 1515-1545.

Fernandez, R., and R.W. Rosenthal, 1990. Strategic models of sovereign-debt renegotiations. Review of Economic Studies, 57, 331-349.

Fernandez-Arias, E., 1996. The new wave of private capital inflows: push or pull? Journal of Development Economics, 48(2), 389-418.

Fostel, A., and G. Kaminsky, 2007. Latin America: Access to international capital markets. Good behavior or global liquidity? National Bureau of Economic Analysis, NBER Working Paper No. 13194.

Gelos, R., Gaston, R.S., and G. Sandleris, 2011. Sovereign borrowing by developing countries: What determines market access? Journal of International Economics, 83(2), 243-254.

Gelos, G.R., Wei, S.-J., 2005. Transparency and international investor behavior. Journal of Finance, 60(6), 2987-3020.

Guembel, A., and O. Sussman, 2009. Sovereign debt without default penalties. Review of Economic Studies, 76(4), 1297-1320.

Kaminsky, G., Lizondo, S., and C. Reinhart, 1998. Leading indicators of currency crises. IMF Staff Papers, 45, 1-48.

Kaminsky, G., and S. Schmukler, 2002. Emerging market instability: Do sovereign ratings affect country risk and stock returns? World Bank Economic Review, 16(2), 171-195.

Kapur, S., Fostel, A., and L. Catão, 2007. Persistent gaps, volatility types, and default traps. International Monetay Fund, IMF Working Paper No. 148.

Kiefer, N.M., 1983. An integral occuring in duration models with heterogeneity. Economics Letters, 11(3), 251-256.

Kiefer, N.M., 1984. A simple test for heterogeneity in exponential models of duration. Journal of Labor Economics, 2(4), 539-549.

Kiefer, N., 1988. Economic duration data and hazard functions. Journal of Economic Literature, 26, 646-679.

Kletzer, K., and B. Wright, 2000. Sovereign debt as intertemporal barter. American Economic Review, 90(3), 621-639. 
Kohlscheen, E., and S.A.O. Connell, 2007. Trade credit, international reserves and sovereign debt. University of Warwick, Warwick Economics Research Paper Series (TWERPS) No. 833.

Lunde, A., and A. Timmermann, 2004. Duration dependence in stock prices: An analysis of bull and bear markets. Journal of Business \& Economic Statistics, 22(3), 253-273.

Mauro, P., Sussman, N., and Y. Yafeh, 2006. Emerging markets and financial globalisation: Sovereign bond spreads in 1870-1913 and today. Oxford: Oxford University Press.

Papaioannou, E., 2009. What drives international financial flows? Politics, institutions and other determinants. Journal of Development Economics, 88(2), 269-281.

Portes, R., and H. Rey, 2005. The determinants of cross-border equity flows. Journal of International Economics, 65 (2), 269-296.

Reinhart, C.M., and K. Rogoff, 2004. Serial default and the 'paradox' of risk-to-poor capital flows. American Economic Review, 94(2), 53-58.

Reinhart, C.M., and E. Talvi, 1998. Capital flows and saving in Latin America and Asia: a reinterpretation. Journal of Development Economics, 57(1), 45-66.

Sandleris, G., 2008. Sovereign defaults: Information, investment and credit. Journal of International Economics, 76(2), 267-275.

Sichel, D., 1991. Business cycle duration dependence: A parametric approach. Review of Economics and Statistics, 73, 254-260.

Sturzenegger, F., and J. Zettelmeyer, 2007. Debt defaults and lessons from a decade of crises. MIT Press.

Trebesch, C., 2008. Delays in debt restructurings. Should we really blame the creditors? Proceedings of the German Development Economics Conference, Zurich, No. 44.

Wei, S.-J., 2000. Local corruption and global capital flows. Brookings Papers on Economic Activity, 2, 303-354.

Zanforlin, L., 2007. Re-accessing international capital markets after financial crises: Some empirical evidence. International Monetary Fund, IMF Working Paper No. 136. 
List of Tables

Table 1. Descriptive statistics.

\begin{tabular}{lccccc}
\hline \hline Variables & No. Observations & Mean & Standard deviation & Minimum & Maximum \\
\hline & \multicolumn{5}{c}{ Exit from } \\
\hline Exit spells & 561 & 3.55 & 3.68 & 1 & 30 \\
Order of event & 561 & 3.44 & 2.11 & 1 & 11 \\
Duration of previous event & 561 & 3.43 & 4.08 & 0 & 33 \\
Default episodes & 363 & 0.94 & 0.23 & 0 & 1 \\
IMF-supported program & 561 & 0.58 & 0.49 & 0 & 1 \\
Country size & 561 & 0.10 & 0.30 & 0 & 1 \\
Economic risk rating & 317 & 0.45 & 0.50 & 0 & 1 \\
Financial risk rating & 317 & 0.51 & 0.50 & 0 & 1 \\
Political risk rating & 317 & 0.33 & 0.47 & 0 & 1 \\
\hline & \multicolumn{7}{c}{ Re-entry to international capital markets } & \\
\hline Re-entry spells & 614 & 4.29 & 5.71 & 1 & 42 \\
Order of event & 614 & 3.47 & 2.10 & 1 & 11 \\
Duration of previous event & 614 & 2.92 & 3.44 & 0 & 24 \\
Default episodes & 377 & 0.95 & 0.22 & 0 & 1 \\
IMF-supported program & 614 & 0.57 & 0.50 & 0 & 1 \\
Country size & 614 & 0.10 & 0.30 & 0 & 1 \\
Economic risk rating & 322 & 0.39 & 0.49 & 0 & 1 \\
Financial risk rating & 322 & 0.52 & 0.50 & 0 & 1 \\
Political risk rating & 322 & 0.33 & 0.47 & 0 & 1 \\
\hline
\end{tabular}

Notes: This Table reports the number of observations, the mean duration, the standard deviation, the minimum and the maximum duration for each spell. Similar statistics are reported for the various regressors that are assumed to be constant over each spell. Data comprise 121 developed and developing countries over the period 1970-2011. 
Table 2. Exit from international capital markets: baseline Weibull model.

\begin{tabular}{|c|c|c|c|c|c|}
\hline & $(1)$ & $(2)$ & (3) & $(4)$ & (5) \\
\hline$\gamma$ & $0.1913 * * *$ & $0.0347 * * *$ & $0.0082 * *$ & 0.0163* & 0.0106 \\
\hline \multirow{2}{*}{$\mathrm{p}$} & $1.1359^{+, \mathrm{d}}$ & $1.2405^{+, \mathrm{d}}$ & $1.3261^{+, \mathrm{d}}$ & $1.3671^{+, \mathrm{d}}$ & $1.3811^{+, \mathrm{d}}$ \\
\hline & $(0.0376)$ & $(0.0304)$ & $(0.0340)$ & $(0.0441)$ & (0.0559) \\
\hline \multirow{2}{*}{ Asia-Pacific } & & $1.4251 * * *$ & $1.7331 * * *$ & $1.5339 * * *$ & $1.6220 * * *$ \\
\hline & & $(0.2993)$ & $(0.3192)$ & $(0.4152)$ & $(0.4607)$ \\
\hline \multirow[t]{2}{*}{ Latin America } & & $1.5802 * * *$ & $1.6941 * * *$ & $1.5757 * * *$ & $1.2455^{* * *}$ \\
\hline & & $(0.2907)$ & $(0.3092)$ & $(0.3845)$ & (0.3943) \\
\hline \multirow[t]{2}{*}{ Middle East } & & $1.9108 * * *$ & $2.1537 * * *$ & $1.8064^{* * *}$ & $1.7631^{* * *}$ \\
\hline & & (0.3318) & (0.3184) & (0.3993) & (0.3857) \\
\hline \multirow{2}{*}{ Africa } & & $1.4159 * * *$ & $1.6066 * * *$ & $1.4330 * * *$ & $1.4279 * * *$ \\
\hline & & $(0.3071)$ & $(0.3159)$ & (0.3885) & (0.3859) \\
\hline \multirow[t]{2}{*}{ Europe } & & $1.9997 * * *$ & $2.7190 * * *$ & $2.4339 * * *$ & $2.5221^{* * *}$ \\
\hline & & (0.3399) & $(0.3913)$ & $(0.4909)$ & $(0.5093)$ \\
\hline \multirow[t]{2}{*}{ Dec70 } & & $0.7858 * * *$ & $1.5884 * * *$ & $1.9266^{* * *}$ & omitted \\
\hline & & $(0.1501)$ & $(0.2190)$ & $(0.3072)$ & \\
\hline \multirow[t]{2}{*}{ Dec80 } & & $0.2690 *$ & $0.7302 * * *$ & $0.9923 * * *$ & $1.1296 * * *$ \\
\hline & & (0.1548) & (0.1695) & $(0.2276)$ & (0.2809) \\
\hline \multirow[t]{2}{*}{ Dec90 } & & -0.0835 & 0.1329 & 0.2012 & $0.3793 * *$ \\
\hline & & $(0.1520)$ & $(0.1482)$ & $(0.1579)$ & $(0.1763)$ \\
\hline \multirow[t]{2}{*}{ Order of event } & & & $0.2520 * * *$ & $0.2410^{* * *}$ & $0.2696 * * *$ \\
\hline & & & $(0.0398)$ & $(0.0499)$ & $(0.0614)$ \\
\hline \multirow{2}{*}{ Duration of previous event } & & & 0.0012 & $-0.0673 * * *$ & $-0.0932 * * *$ \\
\hline & & & $(0.0208)$ & $(0.0238)$ & $(0.0274)$ \\
\hline \multirow[t]{2}{*}{ Default episodes } & & & & $-0.3229 *$ & 0.0760 \\
\hline & & & & $(0.1853)$ & $(0.5206)$ \\
\hline \multirow[t]{2}{*}{ IMF-supported program } & & & & $-0.3983^{* *}$ & $-0.5594 * * *$ \\
\hline & & & & $(0.1835)$ & $(0.2108)$ \\
\hline \multirow[t]{2}{*}{ Country size } & & & & 0.2115 & 0.0667 \\
\hline & & & & $(0.1946)$ & $(0.2510)$ \\
\hline \multirow{2}{*}{ Economic risk rating } & & & & & -0.0566 \\
\hline & & & & & $(0.1734)$ \\
\hline \multirow[t]{2}{*}{ Financial risk rating } & & & & & -0.1114 \\
\hline & & & & & $(0.1849)$ \\
\hline \multirow[t]{2}{*}{ Political risk rating } & & & & & $0.4767 * * *$ \\
\hline & & & & & $(0.1800)$ \\
\hline Spells & 561 & 561 & 561 & 363 & 255 \\
\hline $\log L$ & -733.2 & -657.6 & -630.1 & -400.0 & -276.5 \\
\hline SBIC & 1479.0 & 1378.5 & 1336.2 & 888.1 & 647.2 \\
\hline
\end{tabular}

Notes: Heteroscedasticity and serial autocorrelation robust standard errors clustered by country are reported in brackets; ${ }^{+}$indicates that $p$ is significantly higher than 1 using a one-sided test with a $5 \%$ significance level; d, c, and i indicate decreasing, constant or increasing positive duration dependence, respectively; ${ }^{-}$indicates negative duration dependence; $* * *, * *, *-$ statistically significant at $1 \%, 5 \%$, and $10 \%$ level, respectively. The Schwartz Bayesian information criterion (SBIC) is computed as follows: $\mathrm{SBIC}=2(-\log \mathrm{L}+(k / 2) \log N)$, where, $\log L$ is the value of the log likelihood function, $k$ is the number of regressors and $N$ is the number of observations (spells). 
Table 3. Re-entry to international capital markets: baseline Weibull model.

\begin{tabular}{|c|c|c|c|c|c|}
\hline & $(1)$ & $(2)$ & (3) & (4) & (5) \\
\hline$\gamma$ & $\begin{array}{c}0.2226 * * * \\
(0.0120)\end{array}$ & $\begin{array}{c}0.0269 * * * \\
(0.0059)\end{array}$ & $\begin{array}{c}0.0042 * * * \\
(0.0013)\end{array}$ & $\begin{array}{c}0.0076 * * \\
(0.0032)\end{array}$ & $\begin{array}{c}0.0068 * * \\
(0.0032)\end{array}$ \\
\hline $\mathrm{p}$ & $\begin{array}{c}0.9308^{-} \\
(0.0328)\end{array}$ & $\begin{array}{l}1.1218^{+, \mathrm{d}} \\
(0.0318)\end{array}$ & $\begin{array}{l}1.2885^{+, \mathrm{d}} \\
(0.0344)\end{array}$ & $\begin{array}{l}1.3303^{+, \mathrm{d}} \\
(0.0503)\end{array}$ & $\begin{array}{l}1.3943^{+, d} \\
(0.0644)\end{array}$ \\
\hline Asia-Pacific & & $\begin{array}{c}1.9251 * * * \\
(0.3211)\end{array}$ & $\begin{array}{c}1.9466^{* * *} \\
(0.2525)\end{array}$ & $\begin{array}{c}1.9111^{* * *} \\
(0.3072)\end{array}$ & $\begin{array}{c}1.8648 * * * \\
(0.3670)\end{array}$ \\
\hline Latin America & & $\begin{array}{c}2.2294 * * * \\
(0.2592)\end{array}$ & $\begin{array}{c}1.9201^{* * *} \\
(0.2236)\end{array}$ & $\begin{array}{c}2.0535^{* * *} \\
(0.2675)\end{array}$ & $\begin{array}{c}2.3344 * * * \\
(0.3270)\end{array}$ \\
\hline Middle East & & $\begin{array}{c}1.8251^{* * *} \\
(0.3286)\end{array}$ & $\begin{array}{c}1.6899 * * * \\
(0.2804)\end{array}$ & $\begin{array}{c}1.8710^{* * *} \\
(0.3608)\end{array}$ & $\begin{array}{c}1.9655 * * * \\
(0.5029)\end{array}$ \\
\hline Africa & & $\begin{array}{c}2.0291^{* * *} \\
(0.2741)\end{array}$ & $\begin{array}{c}1.8452^{* * *} \\
(0.2365)\end{array}$ & $\begin{array}{c}2.0540 * * * \\
(0.2880)\end{array}$ & $\begin{array}{c}2.4000 * * * \\
(0.3157)\end{array}$ \\
\hline Europe & & $\begin{array}{c}1.8460^{* * *} \\
(0.2794)\end{array}$ & $\begin{array}{c}2.3932 * * * \\
(0.3008) \\
\end{array}$ & $\begin{array}{c}2.1623^{* * *} \\
(0.3931)\end{array}$ & $\begin{array}{c}2.2648 * * * \\
(0.4581)\end{array}$ \\
\hline Dec70 & & $\begin{array}{l}0.3381^{*} \\
(0.1822)\end{array}$ & $\begin{array}{c}1.6013^{* * *} \\
(0.2158)\end{array}$ & $\begin{array}{c}1.2669 * * * \\
(0.3238)\end{array}$ & omitted \\
\hline Dec80 & & $\begin{array}{c}-0.0373 \\
(0.1825)\end{array}$ & $\begin{array}{c}0.8538 * * * \\
(0.2074)\end{array}$ & $\begin{array}{c}0.7864 * * * \\
(0.3049)\end{array}$ & $\begin{array}{l}0.6351^{*} \\
(0.3546)\end{array}$ \\
\hline Dec90 & & $\begin{array}{c}0.3847^{* *} \\
(0.1685) \\
\end{array}$ & $\begin{array}{c}0.6217 * * * \\
(0.1679)\end{array}$ & $\begin{array}{c}0.2061 \\
(0.2137) \\
\end{array}$ & $\begin{array}{c}0.0719 \\
(0.2167) \\
\end{array}$ \\
\hline Order of event & & & $\begin{array}{c}0.3249 * * * \\
(0.0310)\end{array}$ & $\begin{array}{c}0.2412 * * * \\
(0.0433)\end{array}$ & $\begin{array}{c}0.1241^{* *} \\
(0.0486)\end{array}$ \\
\hline Duration of previous event & & & $\begin{array}{c}0.0675^{* * *} \\
(0.0158)\end{array}$ & $\begin{array}{c}0.0641 * * * \\
(0.0195)\end{array}$ & $\begin{array}{c}0.0498^{* *} \\
(0.0214) \\
\end{array}$ \\
\hline Default episodes & & & & $\begin{array}{c}0.0987 \\
(0.1936)\end{array}$ & $\begin{array}{c}0.3988 \\
(0.2584)\end{array}$ \\
\hline IMF-supported program & & & & $\begin{array}{c}-0.5541 * * * \\
(0.2036)\end{array}$ & $\begin{array}{c}-0.3837 * * \\
(0.1814)\end{array}$ \\
\hline Country size & & & & $\begin{array}{c}0.0755 \\
(0.1926)\end{array}$ & $\begin{array}{c}0.1149 \\
(0.2475)\end{array}$ \\
\hline Economic risk rating & & & & & $\begin{array}{c}0.2444 \\
(0.2113)\end{array}$ \\
\hline Financial risk rating & & & & & $\begin{array}{c}0.1646 \\
(0.2156)\end{array}$ \\
\hline Political risk rating & & & & & $\begin{array}{c}0.0035 \\
(0.2245)\end{array}$ \\
\hline Spells & 614 & 614 & 614 & 377 & 260 \\
\hline $\log L$ & -908.0 & -761.4 & -701.2 & -416.2 & -263.8 \\
\hline SBIC & 1828.6 & 1586.9 & 1479.4 & 921.5 & 622.1 \\
\hline
\end{tabular}

Notes: Heteroscedasticity and serial autocorrelation robust standard errors clustered by country are reported in brackets; ${ }^{+}$indicates that $p$ is significantly higher than 1 using a one-sided test with a $5 \%$ significance level; d, c, and i indicate decreasing, constant or increasing positive duration dependence, respectively; ${ }^{-}$indicates negative duration dependence; $* * *, * *, *-$ statistically significant at $1 \%, 5 \%$, and $10 \%$ level, respectively. The Schwartz Bayesian information criterion (SBIC) is computed as follows: $\mathrm{SBIC}=2(-\operatorname{LogL}+(k / 2) \log N)$, where, $\log L$ is the value of the log likelihood function, $k$ is the number of regressors and $N$ is the number of observations (spells). 
Table 4. Exit and re-entry to international capital markets: Weibull model with a change-point.

\begin{tabular}{|c|c|c|c|c|c|c|c|c|c|c|}
\hline & \multicolumn{5}{|c|}{ Exit } & \multicolumn{5}{|c|}{ Re-entry } \\
\hline & (1) & (2) & (3) & (4) & (5) & (6) & (7) & (8) & (9) & (10) \\
\hline$\gamma_{1}$ & $\begin{array}{c}0.2379 * * * \\
(0.0098)\end{array}$ & $\begin{array}{c}0.0892^{* * *} \\
(0.0085)\end{array}$ & $\begin{array}{c}0.4832 * * * \\
(0.1568)\end{array}$ & $\begin{array}{c}0.1429 * * * \\
(0.0052)\end{array}$ & $\begin{array}{c}0.1126^{* *} \\
(0.0516)\end{array}$ & $\begin{array}{c}0.2242 * * * \\
(0.0121)\end{array}$ & $\begin{array}{c}0.2270^{* * *} \\
(0.0392)\end{array}$ & $\begin{array}{c}0.2643 * * * \\
(0.0651)\end{array}$ & $\begin{array}{c}0.1239 * * * \\
(0.0389)\end{array}$ & $\begin{array}{c}0.0513^{* * *} \\
(0.0166)\end{array}$ \\
\hline$\gamma_{2}$ & $\begin{array}{l}0.6777^{*} \\
(0.3690)\end{array}$ & $\begin{array}{c}0.0921^{* * *} \\
(0.0111)\end{array}$ & $\begin{array}{c}0.5885^{* *} \\
(0.2917)\end{array}$ & $\begin{array}{c}0.1481^{* * *} \\
(0.0176)\end{array}$ & $\begin{array}{l}0.1155^{*} \\
(0.0653)\end{array}$ & $\begin{array}{c}0.6836^{* * *} \\
(0.2488)\end{array}$ & $\begin{array}{c}0.3388^{* * *} \\
(0.1250)\end{array}$ & $\begin{array}{c}0.3014 * * * \\
(0.1110)\end{array}$ & $\begin{array}{c}0.1256 * * * \\
(0.0460)\end{array}$ & $\begin{array}{c}0.0298 * * \\
(0.0147)\end{array}$ \\
\hline $\mathrm{p}_{1}$ & $\begin{array}{l}1.1911^{+, \mathrm{d}} \\
(0.0298)\end{array}$ & $\begin{array}{l}1.2660^{+, \mathrm{d}} \\
(0.0296)\end{array}$ & $\begin{array}{l}1.3319^{+, d} \\
(0.0345)\end{array}$ & $\begin{array}{l}1.3708^{+, \mathrm{d}} \\
(0.0437)\end{array}$ & $\begin{array}{l}1.3868^{+, d} \\
(0.0547)\end{array}$ & $\begin{array}{l}1.1200^{+, \mathrm{d}} \\
(0.0327)\end{array}$ & $\begin{array}{l}1.1950^{+, \mathrm{d}} \\
(0.0358)\end{array}$ & $\begin{array}{l}1.3076^{+, \mathrm{d}} \\
(0.0397)\end{array}$ & $\begin{array}{l}1.3425^{+, \mathrm{d}} \\
(0.0577)\end{array}$ & $\begin{array}{l}1.4308^{+, \mathrm{d}} \\
(0.0704)\end{array}$ \\
\hline $\mathrm{p}_{2}$ & $\begin{array}{c}0.5962^{-} \\
(0.1453)\end{array}$ & $\begin{array}{c}0.8708 \\
(0.1540)\end{array}$ & $\begin{array}{c}0.9476 \\
(0.1962)\end{array}$ & $\begin{array}{c}0.9754 \\
(0.2461)\end{array}$ & $\begin{array}{c}0.9772 \\
(0.2678)\end{array}$ & $\begin{array}{c}0.4326^{-} \\
(0.0643)\end{array}$ & $\begin{array}{c}0.7659^{-} \\
(0.1030)\end{array}$ & $\begin{array}{c}0.8351 \\
(0.1348)\end{array}$ & $\begin{array}{c}0.7953 \\
(0.2176)\end{array}$ & $\begin{array}{c}0.8402 \\
(0.2885)\end{array}$ \\
\hline $\mathrm{p}_{2}-\mathrm{p}_{1}$ & $\begin{array}{c}-0.5948^{* * * *} \\
(0.1498)\end{array}$ & $\begin{array}{c}-0.3952^{* *} \\
(0.1616)\end{array}$ & $\begin{array}{c}-0.3843^{* *} \\
(0.1759)\end{array}$ & $\begin{array}{c}-0.3954^{* *} \\
(0.2014)\end{array}$ & $\begin{array}{c}-0.4096^{* *} \\
(0.2059)\end{array}$ & $\begin{array}{c}-0.6874 * * * \\
(0.0796)\end{array}$ & $\begin{array}{c}-0.4291^{* * * *} \\
(0.1214)\end{array}$ & $\begin{array}{c}-0.4725^{* * *} \\
(0.1517)\end{array}$ & $\begin{array}{c}-0.5472^{* *} \\
(0.2423)\end{array}$ & $\begin{array}{c}-0.5906^{* *} \\
(0.2731)\end{array}$ \\
\hline Asia-Pacific & & $\begin{array}{c}1.3918^{* * *} \\
(0.2849)\end{array}$ & $\begin{array}{c}1.7167^{* * *} \\
(0.3126)\end{array}$ & $\begin{array}{c}1.5191^{* * *} \\
(0.4109)\end{array}$ & $\begin{array}{c}1.5989 * * * \\
(0.4589)\end{array}$ & & $\begin{array}{c}1.8374 * * * \\
(0.2913)\end{array}$ & $\begin{array}{c}1.9074^{* * *} \\
(0.2525)\end{array}$ & $\begin{array}{c}1.8739 * * * \\
(0.3122)\end{array}$ & $\begin{array}{c}1.7057^{* * *} \\
(0.3730)\end{array}$ \\
\hline Latin America & & $\begin{array}{c}1.5483 * * * \\
(0.2784)\end{array}$ & $\begin{array}{c}1.6803^{* * *} \\
(0.3040)\end{array}$ & $\begin{array}{c}1.5629 * * * \\
(0.3800)\end{array}$ & $\begin{array}{c}1.2278 * * * \\
(0.3881)\end{array}$ & & $\begin{array}{c}2.1107^{* * *} \\
(0.2388)\end{array}$ & $\begin{array}{c}1.8818^{* * * *} \\
(0.2228)\end{array}$ & $\begin{array}{c}2.0181^{* * *} \\
(0.2707)\end{array}$ & $\begin{array}{c}2.1716^{* * * *} \\
(0.3271)\end{array}$ \\
\hline Middle East & & $\begin{array}{c}1.8717 * * * \\
(0.3246)\end{array}$ & $\begin{array}{c}2.1367 * * * \\
(0.3142)\end{array}$ & $\begin{array}{c}1.7910^{* * *} \\
(0.3958)\end{array}$ & $\begin{array}{c}1.7439 * * * \\
(0.3814)\end{array}$ & & $\begin{array}{c}1.7137 * * * \\
(0.3090)\end{array}$ & $\begin{array}{c}1.6512^{* * * *} \\
(0.2782)\end{array}$ & $\begin{array}{c}1.8294 * * * \\
(0.3613)\end{array}$ & $\begin{array}{c}1.7942 * * * \\
(0.5041)\end{array}$ \\
\hline Africa & & $\begin{array}{c}1.3874 * * * \\
(0.2916)\end{array}$ & $\begin{array}{c}1.5922 * * * \\
(0.3100)\end{array}$ & $\begin{array}{c}1.4196 * * * \\
(0.3830)\end{array}$ & $\begin{array}{c}1.4109 * * * \\
(0.3754)\end{array}$ & & $\begin{array}{c}1.9454^{* * *} \\
(0.2480)\end{array}$ & $\begin{array}{c}1.8154^{* * * *} \\
(0.2336)\end{array}$ & $\begin{array}{c}2.0230 * * * \\
(0.2892)\end{array}$ & $\begin{array}{c}2.2161^{* * * *} \\
(0.3311)\end{array}$ \\
\hline Europe & & $\begin{array}{c}1.9465^{* * *} \\
(0.3307) \\
\end{array}$ & $\begin{array}{c}2.6914^{* * *} \\
(0.3830) \\
\end{array}$ & $\begin{array}{c}2.4108^{* * *} \\
(0.4846) \\
\end{array}$ & $\begin{array}{c}2.4940^{* * *} \\
(0.5116) \\
\end{array}$ & & $\begin{array}{c}1.7208^{* * *} \\
(0.2597) \\
\end{array}$ & $\begin{array}{c}2.3337 * * * \\
(0.2998) \\
\end{array}$ & $\begin{array}{c}2.1247^{* * *} \\
(0.3867) \\
\end{array}$ & $\begin{array}{c}2.1149 * * * \\
(0.4285)\end{array}$ \\
\hline Dec70 & & $\begin{array}{c}0.7645^{* * *} \\
(0.1486)\end{array}$ & $\begin{array}{c}1.5727^{* * *} \\
(0.2197)\end{array}$ & $\begin{array}{c}1.9134^{* * *} \\
(0.3168)\end{array}$ & & & $\begin{array}{c}0.2346 \\
(0.1680)\end{array}$ & $\begin{array}{c}1.5358^{* * * *} \\
(0.2228)\end{array}$ & $\begin{array}{c}1.2174 * * * \\
(0.3421)\end{array}$ & \\
\hline Dec80 & & $\begin{array}{c}0.2392 \\
(0.1528)\end{array}$ & $\begin{array}{c}0.7164^{* * *} \\
(0.1721)\end{array}$ & $\begin{array}{c}0.9806^{* * *} \\
(0.2352)\end{array}$ & $\begin{array}{c}1.1203^{* * *} \\
(0.2867)\end{array}$ & & $\begin{array}{l}-0.1204 \\
(0.1638)\end{array}$ & $\begin{array}{c}0.8094 * * * \\
(0.2134)\end{array}$ & $\begin{array}{c}0.7494^{* *} \\
(0.3198)\end{array}$ & $\begin{array}{c}0.5663 \\
(0.3531)\end{array}$ \\
\hline Dec90 & & $\begin{array}{l}-0.0972 \\
(0.1462)\end{array}$ & $\begin{array}{c}0.1274 \\
(0.1467)\end{array}$ & $\begin{array}{c}0.1959 \\
(0.1589)\end{array}$ & $\begin{array}{c}0.3757 * * \\
(0.1775)\end{array}$ & & $\begin{array}{l}0.2904^{*} \\
(0.1586)\end{array}$ & $\begin{array}{c}0.5891^{* * * *} \\
(0.1735)\end{array}$ & $\begin{array}{c}0.1898 \\
(0.2214)\end{array}$ & $\begin{array}{c}0.0383 \\
(0.2246)\end{array}$ \\
\hline Order of event & & & $\begin{array}{c}0.2487 * * * \\
(0.0402)\end{array}$ & $\begin{array}{c}0.2382^{* * *} \\
(0.0518)\end{array}$ & $\begin{array}{c}0.2661^{* * *} \\
(0.0644)\end{array}$ & & & $\begin{array}{c}0.3160 * * * \\
(0.0329)\end{array}$ & $\begin{array}{c}0.2352^{* * *} \\
(0.0459)\end{array}$ & $\begin{array}{c}0.1108^{* *} \\
(0.0497)\end{array}$ \\
\hline Duration of prev & Jus event & & $\begin{array}{c}0.0014 \\
(0.0207)\end{array}$ & $\begin{array}{c}-0.0670 * * * \\
(0.0238)\end{array}$ & $\begin{array}{c}-0.0929 * * * \\
(0.0273)\end{array}$ & & & $\begin{array}{c}0.0658^{* * *} \\
(0.0159)\end{array}$ & $\begin{array}{c}0.0623^{* * *} \\
(0.0200)\end{array}$ & $\begin{array}{c}0.0464^{* *} \\
(0.0217)\end{array}$ \\
\hline Default episodes & & & & $\begin{array}{l}-0.3221^{*} \\
(0.1844)\end{array}$ & $\begin{array}{c}0.0786 \\
(0.5180)\end{array}$ & & & & $\begin{array}{c}0.1051 \\
(0.1967)\end{array}$ & $\begin{array}{l}0.4352^{*} \\
(0.2599)\end{array}$ \\
\hline IMF-supported & ogram & & & $\begin{array}{c}-0.3962 * * \\
(0.1830)\end{array}$ & $\begin{array}{c}-0.5562 * * * \\
(0.2109)\end{array}$ & & & & $\begin{array}{c}-0.5427 * * * \\
(0.2028)\end{array}$ & $\begin{array}{c}-0.3761^{* *} \\
(0.1796)\end{array}$ \\
\hline Country size & & & & $\begin{array}{c}0.2104 \\
(0.1944)\end{array}$ & $\begin{array}{c}0.0648 \\
(0.2500)\end{array}$ & & & & $\begin{array}{c}0.0692 \\
(0.1912)\end{array}$ & $\begin{array}{c}0.0901 \\
(0.2507)\end{array}$ \\
\hline Economic risk & & & & & $\begin{array}{l}-0.0544 \\
(0.1734)\end{array}$ & & & & & $\begin{array}{c}0.2286 \\
(0.2119)\end{array}$ \\
\hline Financial risk ra & & & & & $\begin{array}{l}-0.1072 \\
(0.1862)\end{array}$ & & & & & $\begin{array}{c}0.1403 \\
(0.2170)\end{array}$ \\
\hline Political risk rati & & & & & $\begin{array}{c}0.4765^{* * *} \\
(0.1794)\end{array}$ & & & & & $\begin{array}{c}-0.0098 \\
(0.2260)\end{array}$ \\
\hline Spells & 561 & 561 & 561 & 363 & 255 & 614 & 614 & 614 & 377 & 260 \\
\hline LogL & -1149.0 & -1078.0 & -1052.1 & -674.2 & -489.5 & -1313.0 & -1195.0 & -1141.0 & -670.7 & -415.0 \\
\hline SBIC & 2316.9 & 2232.0 & 2186.6 & 1448.6 & 1084.4 & 2645.7 & 2460.2 & 2365.3 & 1436.2 & 930.0 \\
\hline
\end{tabular}

Notes: Heteroscedasticity and serial autocorrelation robust standard errors clustered by country are reported in brackets; ${ }^{+}$indicates that $p$ is significantly higher than 1 using a one-sided test with a $5 \%$ significance level; d, c, and i indicate decreasing, constant or increasing positive duration dependence, respectively. ${ }^{-}$indicates negative duration dependence; $\mathrm{p}_{2}-\mathrm{p}_{1}$ is the estimated difference in the duration dependence parameters. The change-points are 12 and 9 years for market exit and re-entry, respectively. Columns 1 to 5 present the results for market exit for which the change-point is located at duration equal to 12 years. Columns 6 to 10 present the results for market re-entry for which the change-point is located at duration equal to 9 years. 
Table 5. Exit and re-entry to international capital markets: Sensitivity analysis (I).

\begin{tabular}{|c|c|c|c|c|c|c|c|c|}
\hline & \multicolumn{4}{|c|}{ Exit } & \multicolumn{4}{|c|}{ Re-entry } \\
\hline & $\begin{array}{c}\text { Length of } \\
\text { default }\end{array}$ & $\begin{array}{l}\text { Size of } \\
\text { haircut }\end{array}$ & $\begin{array}{c}\text { Defaulting } \\
\text { countries }\end{array}$ & $\begin{array}{l}\text { Excluding } \\
\text { OECD }\end{array}$ & $\begin{array}{c}\text { Length of } \\
\text { default }\end{array}$ & $\begin{array}{l}\text { Size of } \\
\text { haircut }\end{array}$ & $\begin{array}{l}\text { Defaulting } \\
\text { countries }\end{array}$ & $\begin{array}{l}\text { Excluding } \\
\text { OECD }\end{array}$ \\
\hline & (1) & (2) & (3) & (4) & (5) & (6) & (7) & (8) \\
\hline$\gamma_{1}$ & $\begin{array}{l}0.0897 * * \\
(0.0372)\end{array}$ & $\begin{array}{c}0.0899 * * * \\
(0.0039)\end{array}$ & $\begin{array}{l}0.1673^{* *} \\
(0.0776)\end{array}$ & $\begin{array}{c}0.1010 \\
(0.0651)\end{array}$ & $\begin{array}{c}0.2590 * * * \\
(0.0808)\end{array}$ & $\begin{array}{l}0.2524 * * \\
(0.0992)\end{array}$ & $\begin{array}{c}0.2509^{* * *} \\
(0.0842)\end{array}$ & $\begin{array}{c}0.0655 * * * \\
(0.0218)\end{array}$ \\
\hline$\gamma_{2}$ & $\begin{array}{c}0.0894 * * * \\
(0.0339)\end{array}$ & $\begin{array}{c}0.0896 * * * \\
(0.0049)\end{array}$ & $\begin{array}{l}0.1740^{*} \\
(0.0954)\end{array}$ & $\begin{array}{c}0.1019 \\
(0.0695)\end{array}$ & $\begin{array}{c}0.4521 \\
(0.4869)\end{array}$ & $\begin{array}{c}0.4217 \\
(0.4239)\end{array}$ & $\begin{array}{c}0.4316 \\
(0.4032)\end{array}$ & $\begin{array}{c}0.0458^{* *} \\
(0.0219)\end{array}$ \\
\hline $\mathrm{p}_{1}$ & $\begin{array}{l}1.3764^{+, d} \\
(0.0566)\end{array}$ & $\begin{array}{l}1.3766^{+, d} \\
(0.0564)\end{array}$ & $\begin{array}{l}1.3883^{+, d} \\
(0.0545)\end{array}$ & $\begin{array}{l}1.3681^{+, d} \\
(0.0563)\end{array}$ & $\begin{array}{l}1.4149^{+, d} \\
(0.0697)\end{array}$ & $\begin{array}{l}1.4177^{+, d} \\
(0.0690)\end{array}$ & $\begin{array}{l}1.4219^{+, d} \\
(0.0692)\end{array}$ & $\begin{array}{l}1.4227^{+, d} \\
(0.0694)\end{array}$ \\
\hline $\mathrm{p}_{2}$ & $\begin{array}{c}0.9690 \\
(0.2999)\end{array}$ & $\begin{array}{c}0.9698 \\
(0.2979)\end{array}$ & $\begin{array}{c}1.014 \\
(0.2726)\end{array}$ & $\begin{array}{c}0.9117 \\
(0.2825)\end{array}$ & $\begin{array}{c}0.8534 \\
(0.3326)\end{array}$ & $\begin{array}{c}0.8721 \\
(0.3350)\end{array}$ & $\begin{array}{c}0.8535 \\
(0.2948)\end{array}$ & $\begin{array}{c}0.8500 \\
(0.2970)\end{array}$ \\
\hline $\mathrm{p}_{2}-\mathrm{p}_{1}$ & $\begin{array}{c}-0.4074^{* *} \\
(0.2077)\end{array}$ & $\begin{array}{c}-0.4068 * * \\
(0.1961)\end{array}$ & $\begin{array}{c}-0.3743^{* *} \\
(0.1698)\end{array}$ & $\begin{array}{c}-0.4564^{* *} \\
(0.2083)\end{array}$ & $\begin{array}{c}-0.5614^{* *} \\
(0.2525)\end{array}$ & $\begin{array}{c}-0.5456 * * \\
(0.2571)\end{array}$ & $\begin{array}{c}-0.5684^{* *} \\
(0.2660)\end{array}$ & $\begin{array}{c}-0.5728 * * \\
(0.2691)\end{array}$ \\
\hline Asia-Pacific & $\begin{array}{c}1.9041 * * * \\
(0.5095)\end{array}$ & $\begin{array}{c}1.9481 * * * \\
(0.5143)\end{array}$ & $\begin{array}{c}1.7468 * * * \\
(0.4592)\end{array}$ & $\begin{array}{c}1.5834 * * * \\
(0.4714)\end{array}$ & $\begin{array}{c}1.8072^{* * * *} \\
(0.4529)\end{array}$ & $\begin{array}{c}1.7486 * * * \\
(0.4687)\end{array}$ & $\begin{array}{c}1.7470 * * * \\
(0.3783)\end{array}$ & $\begin{array}{c}1.7386 * * * \\
(0.4025)\end{array}$ \\
\hline Latin America & $\begin{array}{c}1.2224^{* * *} \\
(0.4450)\end{array}$ & $\begin{array}{c}1.2373 * * * \\
(0.4478)\end{array}$ & $\begin{array}{c}1.2930 * * * \\
(0.3984)\end{array}$ & $\begin{array}{c}1.1461 * * * \\
(0.3913)\end{array}$ & $\begin{array}{c}2.1117 * * * \\
(0.3289)\end{array}$ & $\begin{array}{c}2.0839 * * * \\
(0.3380)\end{array}$ & $\begin{array}{c}2.1813 * * * \\
(0.3336)\end{array}$ & $\begin{array}{c}2.1390 * * * \\
(0.3329)\end{array}$ \\
\hline Middle East & $\begin{array}{c}1.7467 * * * \\
(0.4162)\end{array}$ & $\begin{array}{c}1.7741 * * * \\
(0.4060)\end{array}$ & $\begin{array}{c}1.8047 * * * \\
(0.3881)\end{array}$ & $\begin{array}{c}1.7237 * * * \\
(0.3876)\end{array}$ & $\begin{array}{c}2.2952 * * * \\
(0.5799)\end{array}$ & $\begin{array}{c}2.2994 * * * \\
(0.5844)\end{array}$ & $\begin{array}{c}1.8189 * * * \\
(0.5132)\end{array}$ & $\begin{array}{c}1.8600 * * * \\
(0.5132)\end{array}$ \\
\hline Africa & $\begin{array}{c}1.3703 * * * \\
(0.4162)\end{array}$ & $\begin{array}{c}1.3765 * * * \\
(0.4169)\end{array}$ & $\begin{array}{c}1.4985 * * * \\
(0.3811)\end{array}$ & $\begin{array}{c}1.3866 * * * \\
(0.3774)\end{array}$ & $\begin{array}{c}2.1497 * * * \\
(0.3475)\end{array}$ & $\begin{array}{c}2.1622 * * * \\
(0.3340)\end{array}$ & $\begin{array}{c}2.2182 * * * \\
(0.3391)\end{array}$ & $\begin{array}{c}2.1938 * * * \\
(0.3438)\end{array}$ \\
\hline Europe & $\begin{array}{c}2.6538 * * * \\
(0.6561)\end{array}$ & $\begin{array}{c}2.7394 * * * \\
(0.6401)\end{array}$ & $\begin{array}{c}2.6507 * * * \\
(0.5202)\end{array}$ & $\begin{array}{c}2.5291 * * * \\
(0.6230)\end{array}$ & $\begin{array}{c}2.0613 * * * \\
(0.6533)\end{array}$ & $\begin{array}{c}2.0568 * * * \\
(0.6425)\end{array}$ & $\begin{array}{c}2.1082^{* * * *} \\
(0.4393)\end{array}$ & $\begin{array}{c}1.9541 * * * \\
(0.6306)\end{array}$ \\
\hline Dec80 & $\begin{array}{c}1.1652 * * * \\
(0.2694)\end{array}$ & $\begin{array}{c}1.1572 * * * \\
(0.2709)\end{array}$ & $\begin{array}{c}1.1944 * * * \\
(0.2889)\end{array}$ & $\begin{array}{c}1.2228 * * * \\
(0.3006)\end{array}$ & $\begin{array}{l}0.6162 * \\
(0.3566)\end{array}$ & $\begin{array}{l}0.6521 * \\
(0.3523)\end{array}$ & $\begin{array}{c}0.5750 \\
(0.3651)\end{array}$ & $\begin{array}{l}0.6105^{*} \\
(0.3629)\end{array}$ \\
\hline Dec90 & $\begin{array}{c}0.4933^{* *} \\
(0.2054)\end{array}$ & $\begin{array}{l}0.4947 * * \\
(0.2028)\end{array}$ & $\begin{array}{l}0.4042^{* *} \\
(0.1875)\end{array}$ & $\begin{array}{l}0.3965^{* *} \\
(0.1903)\end{array}$ & $\begin{array}{l}-0.1088 \\
(0.2393)\end{array}$ & $\begin{array}{l}-0.1095 \\
(0.2394)\end{array}$ & $\begin{array}{c}0.0916 \\
(0.2207)\end{array}$ & $\begin{array}{c}0.0806 \\
(0.2290)\end{array}$ \\
\hline Order of event & $\begin{array}{c}0.2991 * * * \\
(0.0616)\end{array}$ & $\begin{array}{c}0.2967 * * * \\
(0.0598)\end{array}$ & $\begin{array}{c}0.2802 * * * \\
(0.0661)\end{array}$ & $\begin{array}{c}0.2720 * * * \\
(0.0667)\end{array}$ & $\begin{array}{l}0.1081^{* *} \\
(0.0495)\end{array}$ & $\begin{array}{c}0.1092^{* *} \\
(0.0490)\end{array}$ & $\begin{array}{l}0.1106 * * \\
(0.0536)\end{array}$ & $\begin{array}{c}0.1043^{* *} \\
(0.0525)\end{array}$ \\
\hline Duration of previous event & $\begin{array}{c}-0.0784^{* * *} \\
(0.0285)\end{array}$ & $\begin{array}{c}-0.0795^{* * *} \\
(0.0285)\end{array}$ & $\begin{array}{c}-0.0972 * * * \\
(0.0281)\end{array}$ & $\begin{array}{c}-0.0849 * * * \\
(0.0296)\end{array}$ & $\begin{array}{l}0.0418 * \\
(0.0227)\end{array}$ & $\begin{array}{l}0.0443 * \\
(0.0226)\end{array}$ & $\begin{array}{c}0.0447 * * \\
(0.0224)\end{array}$ & $\begin{array}{c}0.0454 * * \\
(0.0224)\end{array}$ \\
\hline Default & & & & $\begin{array}{c}0.0580 \\
(0.5350)\end{array}$ & & & & $\begin{array}{c}0.4264 \\
(0.2783)\end{array}$ \\
\hline IMF-supported program & $\begin{array}{c}-0.4408 * * \\
(0.2117)\end{array}$ & $\begin{array}{c}-0.4588^{* *} \\
(0.2218)\end{array}$ & $\begin{array}{c}-0.5864 * * * \\
(0.2106)\end{array}$ & $\begin{array}{c}-0.5804^{* * *} \\
(0.2161)\end{array}$ & $\begin{array}{c}-0.5212 * * * \\
(0.2011)\end{array}$ & $\begin{array}{c}-0.5523 * * * \\
(0.2047)\end{array}$ & $\begin{array}{c}-0.3677^{* *} \\
(0.1805)\end{array}$ & $\begin{array}{c}-0.3807 * * \\
(0.1909)\end{array}$ \\
\hline Country size & $\begin{array}{c}0.2408 \\
(0.3827)\end{array}$ & $\begin{array}{c}0.2810 \\
(0.3772)\end{array}$ & $\begin{array}{l}-0.0343 \\
(0.2578)\end{array}$ & $\begin{array}{c}0.0302 \\
(0.3141)\end{array}$ & $\begin{array}{c}0.4895 \\
(0.3709)\end{array}$ & $\begin{array}{c}0.4224 \\
(0.3922)\end{array}$ & $\begin{array}{c}0.0896 \\
(0.2735)\end{array}$ & $\begin{array}{l}-0.1033 \\
(0.2831)\end{array}$ \\
\hline Economic risk rating & $\begin{array}{c}0.0406 \\
(0.1718)\end{array}$ & $\begin{array}{c}0.0520 \\
(0.1724)\end{array}$ & $\begin{array}{l}-0.0946 \\
(0.1740)\end{array}$ & $\begin{array}{l}-0.1017 \\
(0.1710)\end{array}$ & $\begin{array}{c}0.1752 \\
(0.2489)\end{array}$ & $\begin{array}{c}0.1520 \\
(0.2457)\end{array}$ & $\begin{array}{c}0.2072 \\
(0.2299)\end{array}$ & $\begin{array}{c}0.1968 \\
(0.2251)\end{array}$ \\
\hline Financial risk rating & $\begin{array}{l}-0.1256 \\
(0.2091)\end{array}$ & $\begin{array}{l}-0.1044 \\
(0.1998)\end{array}$ & $\begin{array}{l}-0.0634 \\
(0.1859)\end{array}$ & $\begin{array}{l}-0.1038 \\
(0.1954)\end{array}$ & $\begin{array}{c}0.1400 \\
(0.2680)\end{array}$ & $\begin{array}{c}0.1342 \\
(0.2678)\end{array}$ & $\begin{array}{c}0.1460 \\
(0.2323)\end{array}$ & $\begin{array}{c}0.1439 \\
(0.2390)\end{array}$ \\
\hline Political risk rating & $\begin{array}{l}0.4161^{* *} \\
(0.1979)\end{array}$ & $\begin{array}{l}0.3890 * * \\
(0.1969)\end{array}$ & $\begin{array}{c}0.5240 * * * \\
(0.1764)\end{array}$ & $\begin{array}{c}0.4474 * * \\
(0.1899)\end{array}$ & $\begin{array}{l}-0.1411 \\
(0.2517)\end{array}$ & $\begin{array}{l}-0.0827 \\
(0.2831)\end{array}$ & $\begin{array}{l}-0.0276 \\
(0.2346)\end{array}$ & $\begin{array}{c}0.0039 \\
(0.2345)\end{array}$ \\
\hline Default length & $\begin{array}{l}-0.0482 \\
(0.1659)\end{array}$ & & & & $\begin{array}{l}-0.0737 \\
(0.2069)\end{array}$ & & & \\
\hline Size of haircut & & $\begin{array}{c}0.0748 \\
(0.1508)\end{array}$ & & & & $\begin{array}{l}-0.1645 \\
(0.2219)\end{array}$ & & \\
\hline Spells & 225 & 225 & 247 & 238 & 229 & 229 & 251 & 246 \\
\hline LogL & -438.8 & -438.8 & -474.1 & -461.6 & -362.9 & -362.6 & -397.4 & -391.3 \\
\hline SBIC & 980.6 & 980.5 & 1041.8 & 1021.6 & 829.1 & 823.0 & 888.8 & 881.7 \\
\hline
\end{tabular}

Notes: Heteroscedasticity and serial autocorrelation robust standard errors clustered by country are reported in brackets; ${ }^{+}$indicates that $p$ is significantly higher than 1 using a one-sided test with a $5 \%$ significance level; d, c, and i indicate decreasing, constant or increasing positive duration dependence, respectively; ${ }^{-}$indicates negative duration dependence; $\mathrm{p}_{2}-\mathrm{p}_{1}$ is the estimated difference in the duration dependence parameters. The change-points are 12 and 9 years for exit and re-entry spells, respectively. In regressions 1 and 5, episodes of default are replaced by a dummy variable that takes value of one if the default length is above the sample average, and zero otherwise; in regressions 2 and 6, episodes of default are replaced by a dummy variable that takes value of one if the haircut size is above the sample average, and zero otherwise; in regressions 3 and 7, we consider only past defaulting countries; and, in regressions 4 and 8, OECD countries are excluded from the analysis. 
Table 6. Exit and re-entry to international capital markets: Sensitivity analysis (II).

\begin{tabular}{|c|c|c|c|c|c|c|}
\hline & \multicolumn{2}{|c|}{ Exit } & \multicolumn{2}{|c|}{ Re-entry } & \multirow{2}{*}{$\begin{array}{c}\text { Exit } \\
\text { Alternative } \\
\text { definition }\end{array}$} & \multirow{2}{*}{$\begin{array}{c}\text { Re-entry } \\
\text { Alternative } \\
\text { definition }\end{array}$} \\
\hline & $\begin{array}{c}\text { Excluding } 1 \\
\text { outlier }\end{array}$ & $\begin{array}{c}\text { Excluding } 3 \\
\text { outliers }\end{array}$ & $\begin{array}{c}\text { Excluding } \\
1 \text { outlier } \\
\end{array}$ & $\begin{array}{c}\text { Excluding } \\
3 \text { outliers } \\
\end{array}$ & & \\
\hline & $(1)$ & $(2)$ & (3) & (4) & (5) & (6) \\
\hline$\gamma_{1}$ & $\begin{array}{c}0.3173 * * * \\
(0.0563)\end{array}$ & $\begin{array}{c}0.1023 \\
(0.0871)\end{array}$ & $\begin{array}{c}0.0512 * * * \\
(0.0166)\end{array}$ & $\begin{array}{c}0.0372 * * * \\
(0.0122)\end{array}$ & $\begin{array}{c}0.1088 \\
(0.0787)\end{array}$ & $\begin{array}{c}0.2340 * * * \\
(0.0753)\end{array}$ \\
\hline$\gamma_{2}$ & $\begin{array}{c}0.3381^{* *} \\
(0.1611)\end{array}$ & $\begin{array}{c}0.0993 \\
(0.0761)\end{array}$ & $\begin{array}{c}0.0297 * * \\
(0.0147)\end{array}$ & $\begin{array}{l}0.0177^{*} \\
(0.0102)\end{array}$ & $\begin{array}{l}0.1025 * \\
(0.0525)\end{array}$ & $\begin{array}{c}0.3580 \\
(0.2224)\end{array}$ \\
\hline $\mathrm{p}_{1}$ & $\begin{array}{l}1.3848^{+, d} \\
(0.0546)\end{array}$ & $\begin{array}{l}1.3815^{+, d} \\
(0.0540)\end{array}$ & $\begin{array}{l}1.4309^{+, d} \\
(0.0704)\end{array}$ & $\begin{array}{l}1.4291^{+, d} \\
(0.0707)\end{array}$ & $\begin{array}{l}1.2866^{+, d} \\
(0.0484)\end{array}$ & $\begin{array}{l}1.4221^{+, d} \\
(0.0632)\end{array}$ \\
\hline $\mathrm{p}_{2}$ & $\begin{array}{c}0.9819 \\
(0.2792)\end{array}$ & $\begin{array}{c}1.0478 \\
(0.2678)\end{array}$ & $\begin{array}{c}0.8403 \\
(0.2886)\end{array}$ & $\begin{array}{c}0.8507 \\
(0.2931)\end{array}$ & $\begin{array}{c}0.9160 \\
(0.3951)\end{array}$ & $\begin{array}{c}0.9054 \\
(0.2631)\end{array}$ \\
\hline $\mathrm{p}_{2}-\mathrm{p}_{1}$ & $\begin{array}{c}-0.4029 * * \\
(0.1777)\end{array}$ & $\begin{array}{c}-0.3337^{* *} \\
(0.1602)\end{array}$ & $\begin{array}{c}-0.5906 * * \\
(0.3006)\end{array}$ & $\begin{array}{l}-0.5784 * \\
(0.2853)\end{array}$ & $\begin{array}{c}-0.3706 * \\
(0.199)\end{array}$ & $\begin{array}{c}-0.5167 * * \\
(0.2614)\end{array}$ \\
\hline Asia-Pacific & $\begin{array}{c}1.5376 * * * \\
(0.4658)\end{array}$ & $\begin{array}{c}1.3646 * * * \\
(0.4513)\end{array}$ & $\begin{array}{c}1.7058^{* * *} \\
(0.3730)\end{array}$ & $\begin{array}{c}1.7599 * * * \\
(0.3812)\end{array}$ & $\begin{array}{c}1.1909 * * * \\
(0.3595)\end{array}$ & $\begin{array}{c}1.4649 * * * \\
(0.3538)\end{array}$ \\
\hline Latin America & $\begin{array}{c}1.1748 * * * \\
(0.3929)\end{array}$ & $\begin{array}{c}1.0324 * * * \\
(0.3786)\end{array}$ & $\begin{array}{c}2.1716 * * * \\
(0.3271)\end{array}$ & $\begin{array}{c}2.2185 * * * \\
(0.3361)\end{array}$ & $\begin{array}{c}0.9892 * * * \\
(0.3377)\end{array}$ & $\begin{array}{c}1.8940 * * * \\
(0.3216)\end{array}$ \\
\hline Middle East & $\begin{array}{c}1.6920^{* * *} \\
(0.3858)\end{array}$ & $\begin{array}{c}1.5635^{* * *} \\
(0.3682)\end{array}$ & $\begin{array}{c}1.7943 * * * \\
(0.5041)\end{array}$ & $\begin{array}{c}1.8399 * * * \\
(0.5113)\end{array}$ & $\begin{array}{c}1.3281^{* * *} \\
(0.3720)\end{array}$ & $\begin{array}{c}1.4774 * * * \\
(0.4314)\end{array}$ \\
\hline Africa & $\begin{array}{c}1.3492 * * * \\
(0.3838)\end{array}$ & $\begin{array}{c}1.2048 * * * \\
(0.3803)\end{array}$ & $\begin{array}{c}2.2161 * * * \\
(0.3311)\end{array}$ & $\begin{array}{c}2.2514 * * * \\
(0.3401)\end{array}$ & $\begin{array}{c}1.2337 * * * \\
(0.3618)\end{array}$ & $\begin{array}{c}1.7323^{* * * *} \\
(0.3480)\end{array}$ \\
\hline Europe & $\begin{array}{c}2.4269 * * * \\
(0.5180)\end{array}$ & $\begin{array}{c}2.2287 * * * \\
(0.5014)\end{array}$ & $\begin{array}{c}2.1152 * * * \\
(0.4285)\end{array}$ & $\begin{array}{c}2.1321 * * * \\
(0.4398)\end{array}$ & $\begin{array}{c}1.7464 * * * \\
(0.4243)\end{array}$ & $\begin{array}{c}1.8799 * * * \\
(0.3879)\end{array}$ \\
\hline Dec80 & $\begin{array}{c}1.1010^{* * *} \\
(0.2876)\end{array}$ & $\begin{array}{c}0.9966 * * * \\
(0.2925)\end{array}$ & $\begin{array}{c}0.5665 \\
(0.3531)\end{array}$ & $\begin{array}{c}0.4947 \\
(0.3538)\end{array}$ & $\begin{array}{c}0.7411^{* *} \\
(0.3162)\end{array}$ & $\begin{array}{c}0.4119 \\
(0.3550)\end{array}$ \\
\hline Dec90 & $\begin{array}{c}0.3758 * * \\
(0.1775) \\
\end{array}$ & $\begin{array}{l}0.3165^{*} \\
(0.1782) \\
\end{array}$ & $\begin{array}{c}0.0383 \\
(0.2246) \\
\end{array}$ & $\begin{array}{c}0.0330 \\
(0.2235) \\
\end{array}$ & $\begin{array}{c}0.2053 \\
(0.2130) \\
\end{array}$ & $\begin{array}{l}-0.0723 \\
(0.2603) \\
\end{array}$ \\
\hline Order of event & $\begin{array}{c}0.2623 * * * \\
(0.0644)\end{array}$ & $\begin{array}{c}0.2433 * * * \\
(0.0644)\end{array}$ & $\begin{array}{l}0.1108 * * \\
(0.0497)\end{array}$ & $\begin{array}{c}0.1089 * * \\
(0.0502)\end{array}$ & $\begin{array}{c}0.2908 * * * \\
(0.0640)\end{array}$ & $\begin{array}{c}0.1789 * * * \\
(0.0581)\end{array}$ \\
\hline Duration of previous event & $\begin{array}{c}-0.0917 * * * \\
(0.0272)\end{array}$ & $\begin{array}{c}-0.0937 * * * \\
(0.0277)\end{array}$ & $\begin{array}{c}0.0464^{* *} \\
(0.0217) \\
\end{array}$ & $\begin{array}{l}0.0394 * \\
(0.0216) \\
\end{array}$ & $\begin{array}{c}-0.0827^{* *} \\
(0.0359)\end{array}$ & $\begin{array}{c}0.0477 * * \\
(0.0243)\end{array}$ \\
\hline Default episodes & $\begin{array}{c}0.0681 \\
(0.5147)\end{array}$ & $\begin{array}{c}0.0144 \\
(0.4960)\end{array}$ & $\begin{array}{l}0.4355^{*} \\
(0.2599)\end{array}$ & $\begin{array}{l}0.4368 * \\
(0.2601)\end{array}$ & $\begin{array}{l}-0.2734 \\
(0.2328)\end{array}$ & $\begin{array}{l}0.3851^{*} \\
(0.2290)\end{array}$ \\
\hline IMF-supported program & $\begin{array}{c}-0.5336 * * \\
(0.2125)\end{array}$ & $\begin{array}{c}-0.5063^{* *} \\
(0.2126)\end{array}$ & $\begin{array}{c}-0.3761^{* *} \\
(0.1796)\end{array}$ & $\begin{array}{c}-0.3574 * * \\
(0.1792)\end{array}$ & $\begin{array}{c}-0.5955^{* *} \\
(0.2686)\end{array}$ & $\begin{array}{c}-0.4015^{* *} \\
(0.1978)\end{array}$ \\
\hline Country size & $\begin{array}{c}0.0703 \\
(0.2494)\end{array}$ & $\begin{array}{c}0.0899 \\
(0.2467)\end{array}$ & $\begin{array}{c}0.0902 \\
(0.2507)\end{array}$ & $\begin{array}{c}0.0961 \\
(0.2511)\end{array}$ & $\begin{array}{c}0.1820 \\
(0.1972)\end{array}$ & $\begin{array}{c}0.0363 \\
(0.1851)\end{array}$ \\
\hline Economic risk rating & $\begin{array}{l}-0.0356 \\
(0.1741)\end{array}$ & $\begin{array}{l}-0.0009 \\
(0.1730)\end{array}$ & $\begin{array}{c}0.2286 \\
(0.2119)\end{array}$ & $\begin{array}{c}0.2102 \\
(0.2115)\end{array}$ & $\begin{array}{c}-0.0395 \\
(0.1864)\end{array}$ & $\begin{array}{l}-0.2887 \\
(0.2122)\end{array}$ \\
\hline Financial risk rating & $\begin{array}{c}-0.1122 \\
(0.1858)\end{array}$ & $\begin{array}{c}-0.1464 \\
(0.1892)\end{array}$ & $\begin{array}{c}0.1404 \\
(0.2171)\end{array}$ & $\begin{array}{c}0.1263 \\
(0.2159)\end{array}$ & $\begin{array}{c}-0.0085 \\
(0.2162)\end{array}$ & $\begin{array}{c}0.2173 \\
(0.2068)\end{array}$ \\
\hline Political risk rating & $\begin{array}{c}0.4615^{* *} \\
(0.1803)\end{array}$ & $\begin{array}{c}0.3880 * * \\
(0.1810)\end{array}$ & $\begin{array}{c}-0.0098 \\
(0.2260)\end{array}$ & $\begin{array}{c}-0.0124 \\
(0.2271)\end{array}$ & $\begin{array}{c}0.3857 * * \\
(0.1841)\end{array}$ & $\begin{array}{l}-0.0848 \\
(0.2041)\end{array}$ \\
\hline Spells & 254 & 250 & 260 & 256 & 233 & 238 \\
\hline $\log L$ & -488.8 & -479.3 & -415.0 & -411.4 & -447.4 & -400.8 \\
\hline SBIC & 1082.9 & 1063.5 & 930.0 & 922.7 & 998.3 & 900.2 \\
\hline
\end{tabular}

Notes: Heteroscedasticity and serial autocorrelation robust standard errors clustered by country are reported in brackets; ${ }^{+}$indicates that $p$ is significantly higher than 1 using a one-sided test with a $5 \%$ significance level; d, c, and i indicate decreasing, constant or increasing positive duration dependence, respectively; ${ }^{-}$indicates negative duration dependence; $\mathrm{p}_{2}-\mathrm{p}_{1}$ is the estimated difference in the duration dependence parameters. The change-points are 12 and 9 years for exit and re-entry spells, respectively. Outliers (i.e. spells with the longest duration) are excluded in regressions 1 to 4: regression 1 excludes Cote d'Ivoire; regression 2 excludes Cote d'Ivoire, Niger, and Nigeria; regression 3 excludes the Central African Republic; and regression 4 excludes the Central African Republic, Somalia, and the Syrian Arab Republic. In regressions 5-6, we consider an alternative identification procedure for exit and reentry spells that takes into account the dynamics of portfolio equity net inflows. 


\section{List of Figures}

Figure 1. Exit and re-entry to international capital markets: Survival functions.
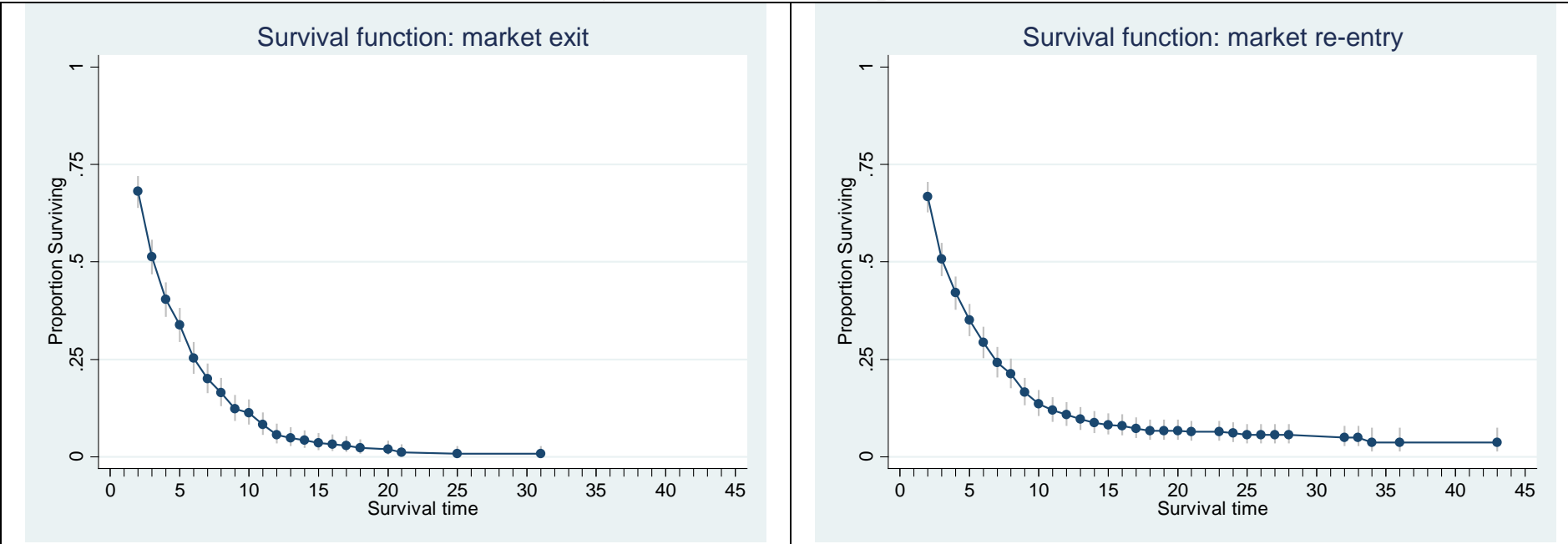

Figure 2. Different potential change-points: $p_{2}-p_{1}$ estimates for the baseline model.

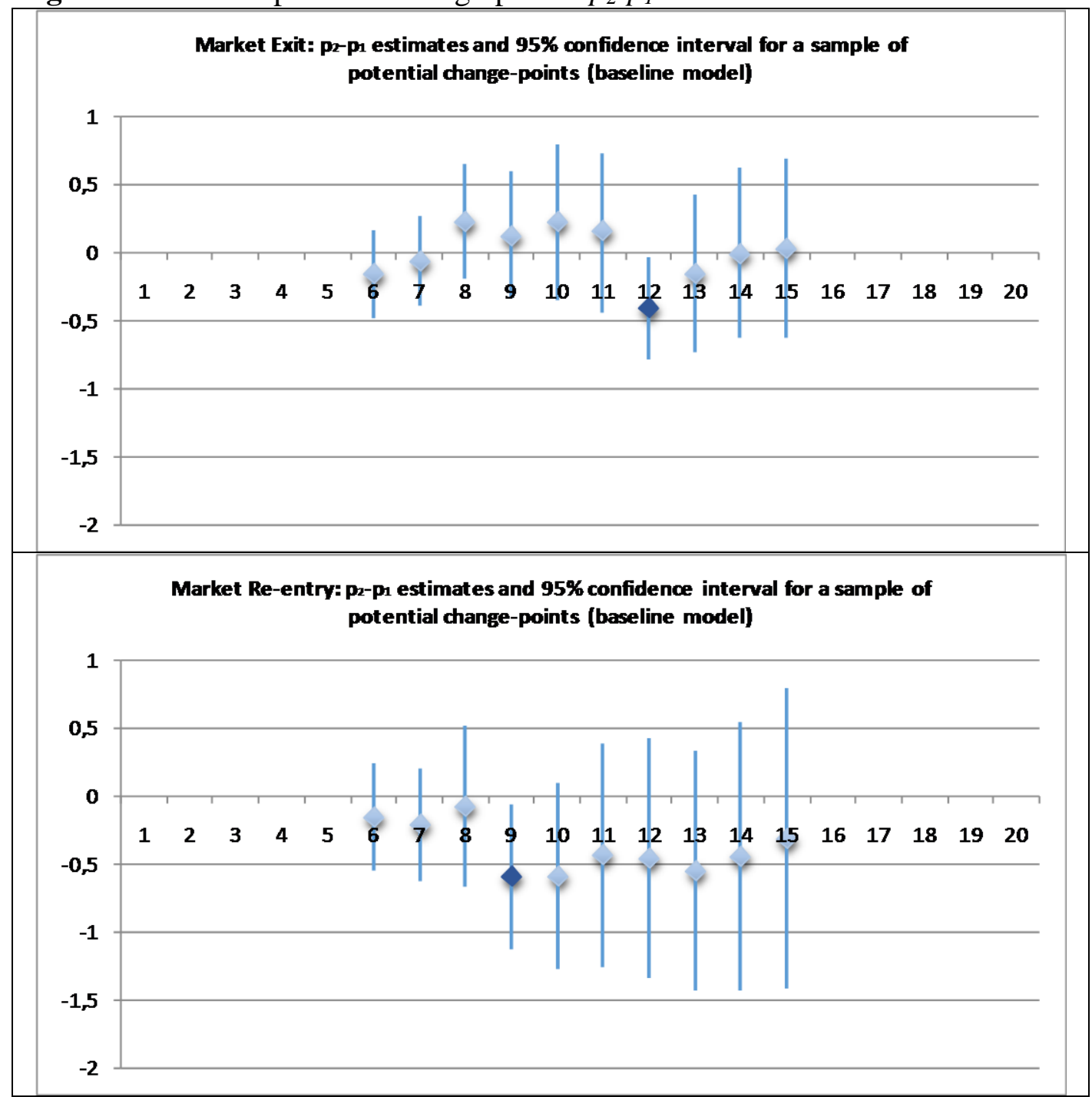




\section{Appendix}

Table A. List of countries included in the sample.

\begin{tabular}{|c|c|c|c|}
\hline Albania & Ecuador & Madagascar & Seychelles \\
\hline Algeria & Egypt, Arab Rep. & Malawi & Sierra Leone \\
\hline Angola & El Salvador & Malaysia & Solomon Islands \\
\hline Argentina & Ethiopia & Maldives & Somalia \\
\hline Armenia & Fiji & Mali & South Africa \\
\hline Azerbaijan & Gabon & Mauritania & Sri Lanka \\
\hline Bangladesh & Gambia, The & Mauritius & St. Lucia \\
\hline Belarus & Georgia & Mexico & St. Vincent and the Grenadines \\
\hline Belize & Ghana & Moldova & Sudan \\
\hline Benin & Grenada & Mongolia & Swaziland \\
\hline Bolivia & Guatemala & Montenegro & Tajikistan \\
\hline Bosnia and Herzegovina & Guinea & Morocco & Tanzania \\
\hline Botswana & Guinea-Bissau & Mozambique & Thailand \\
\hline Brazil & Guyana & Myanmar & Togo \\
\hline Bulgaria & Haiti & Nepal & Tonga \\
\hline Burkina Faso & Honduras & Nicaragua & Tunisia \\
\hline Burundi & India & Niger & Turkey \\
\hline Cameroon & Indonesia & Nigeria & Turkmenistan \\
\hline Cape Verde & Iran, Islamic Rep. & Pakistan & Uganda \\
\hline Chad & Jamaica & Panama & Ukraine \\
\hline Chile & Jordan & Papua New Guinea & Uruguay \\
\hline China & Kazakhstan & Paraguay & Uzbekistan \\
\hline Colombia & Kenya & Peru & Vanuatu \\
\hline Comoros & Kyrgyz Republic & Philippines & Venezuela, RB \\
\hline Congo, Dem. Rep. & Lao PDR & Romania & Vietnam \\
\hline Congo, Rep. & Latvia & Russian Federation & Yemen, Rep. \\
\hline Costa Rica & Lebanon & Rwanda & Zambia \\
\hline Cote d'Ivoire & Lesotho & Samoa & Zimbabwe \\
\hline Djibouti & Liberia & Sao Tome and Principe & \\
\hline Dominica & Lithuania & Senegal & \\
\hline Dominican Republic & Macedonia, FYR & Serbia & \\
\hline
\end{tabular}

